\title{
THE INCIDENCE OF RICKETS IN CHILDREN ATTENDING HOSPITALS IN BRISTOL, FROM SEPTEMBER 1938 TO MAY 1941
}

\author{
BY
}

\author{
BERYL D. CORNER, M.D., M.R.C.P. •
}

Honorary Physician to Out-Patients, Bristol Children's Hospital

\begin{abstract}
At the present time cases of severe rickets in infancy are rarely seen, but it was considered that many infants attending hospitals in the city show evidence of mild rickets clinically. In this investigation an attempt has been made to determine the prevalence of rickets among infants under the age of two years, who were attending hospitals in Bristol during the period from September, 1938, to May, 1941. Particular emphasis has been laid on the diagnosis of mild rickets during the first six months of the infant's life, as at that stage prophylactic measures would appear to be most useful. This particular age group has been neglected by many investigators and Chisholm in her survey of rickets in Manchester in 1933 reports that no cases were found below the age of seven months, using clinical and radiological criteria for diagnosis.
\end{abstract}

The clinical diagnosis of rickets is apt to be uncertain in mild cases, and in the youngest infants $\mathrm{x}$-rays of the wrists will fail to show any abnormality, whereas clinical and histological evidence may be demonstrated in the ribs, owing to the later ossification of the radius (Mackay, 1926). Kay (1930) and other investigators have shown that the plasma phosphatase is increased in rickets, and even when complete healing was shown radiologically, the phosphatase was still above normal limits (Stearns and Warweg, 1933). Smith (1933) has stated that this test is a much more sensitive index of abnormal bone metabolism than estimations of serum calcium or phosphorus. More recently Morris and coworkers (1937) have attempted to assess the value of this test in the diagnosis of rickets, investigating 506 children in Glasgow. They suggested that a rise in phosphatase might be an earlier manifestation of the rachitic state than that provided by clinical or radiological examination.

In view of these findings it was decided to estimate plasma phosphatase in most of the infants examined and an attempt was made to correlate the results with the clinical evidence. X-rays were only used in a few cases, and serum phosphorus and calcium estimations were also available in some cases. Histological examination of the ribs post-mortem was carried out on a few cases.

In addition to examination of the patients, an attempt has been made to collect such information as might have some bearing on the development of rickets. This has included details of feeding and vitamin supplements in every case, previous health of the infant, and type of home environment with particular reference to opportunities for exposure to sunlight. In a certain number of cases information was also obtained about the diet and health of the mother during pregnancy and the general economic level of the family which might affect the diet of the mother and the feeding of the child when mixed feeding has been established.

\section{Method}

The patients investigated were all children below the age of two years who attended for treatment in the following hospital departments, during the period of the investigation :

\section{Bristol Children's Hospital.}

Out-PATIENTS. Cases seen at two medical sessions weekly.

IN-PATIENTS. Medical and surgical wards were visited two or three times weekly and all new admissions were examined.

\section{Bristol Royal INFIRMARY.}

OUT-PATIENTS. Cases seen at the infant-welfare and consultation clinic.

IN-PATIENTS. Cases admitted to the children's ward under the care of Dr. Richard Clarke.

\section{Bristol General Hospital.}

Casualty Department. All children attending for minor medical or surgical conditions under the age of two years were invited to attend at a special session held once weekly for the purpose of this investigation.

Cases already under treatment when the investigation was started have not been included, and most of the patients were at their first or second attendance at hospital, or within three days of admission to a ward.

By this method a random sampling of infants was investigated with all types of medical and surgical conditions as well as a number of healthy children who at tended for routine advice on infant care. 
The number of cases shows a sharp decline during 1940-41 owing to the closure of the obstetric department at the Infirmary, and the consequent cessation of infant-welfare activities at that hospital. In addition air-raids and evacuation caused a considerable decrease in hospital attendances and admissions during that year.

Clinical examination. In every case the disease or condition for which the child attended hospital was noted and also any special points about the previous health. When possible the weight at birth, and weight on examination was obtained and information as to prematurity or twins. The skull was examined for craniotabes, and, in the older children, for the state of the fontanelle. The costo-chondral junctions were examined in every case. No attempt was made to assess enlargement of the epiphyses in the wrist, but in the older children bowing of the legs and the condition of the teeth were noted.

In analysing the cases, the health of the child was classified in the following groups:

1. Healthy. This included all children attending for routine advice, in whom no evidence of past or present ill-health or abnormality could be detected.

2. Minor ailments. In this group were placed minor surgical conditions such as phimosis, or simple hernia, or mild skin conditions in which there was no effect on the general health of the child, or minor medical ailments such as mild coryza.

3. Moderate. In this group were placed children with feeding problems which did not interfere seriously with general nutrition, or with moderate acute illnesses, e.g. acute bronchitis or tonsillitis.

4. Severe. Children in this group were suffering from severe acute or chronic illness, serious surgical operations, or feeding problems of sufficient severity to interfere with gain in weight.

Gain in weight was classified in the following groups:

1. No gain since birth.

2. Less than birth weight.

3. Average gain. This denoted an average weekly increase of weight of 4-6 ounces, during the first six months, at one year approximately three times the birth weight, and during the second year a further gain of 5-6 pounds.

4. 0 to 25 per cent. above average gain.

5. 25 per cent. to 50 per cent. above average gain.

6. 50 per cent. to 100 per cent. àbove average gain.

7. 0 to 25 per cent. below average gain.

8. 25 per cent. to 50 per cent. below average.

9. More than 50 per cent. below average gain.

Clinical examination of the ribs was noted as follows:

1. No beading.

2. Beading plus one. In these cases there is slight enlargement of the costo-chondral junctions.

3. Beading plus two. The enlargement of costochondral junctions is quite definite.

4. Beading plus three. In this group beading is very well marked.
5. Beading plus four, denotes gross beading of the ribs.

No cases were included in the clinically positive groups when delayed dentition or late closure of the fontanelle were the only signs of bony abnormality.

Biochemical tests. Plasma phosphatase was estimated by the micro-chemical method of King, Haslewood and Delory (1937), which is a modification of King and Armstrong's method (1934), and the results are expressed as units of phosphatase activity; these units correspond to the units of Jenner and Kay (1932), the normal range being 510 units per 100 c.c. of plasma. This estimation was performed on every infant in whom it was possible to obtain 2 c.c. of blood, fontanelle puncture being used in many cases. Cases in which the result has been fifteen or more units of phosphatase have been considered to show evidence of active healing, or recently healed rickets, in the absence of any other bone disease which might also give an increased phosphatase activity.

X-rays. The lower ends of the radius and ulna were x-rayed in a few cases, particularly when blood could not be obtained for phosphatase estimation, and in every case the diagnosis has been that reported by the radiologist.

\section{Information relevant to the etiology of rickets}

1. In every case the method of infant feeding was obtained. Length of breast-feeding was recorded in weeks for infants below six months of age, and in months for older children. When artificial feeding with cows' milk has been used, the approximate strength of the milk and water mixture was recorded. Artificial proprietary foods were prepared according to instructions on the tin unless otherwise stated. In the case of older children, the term mixed feeding. has been used to imply a diet consisting of cereals, vegetables, bread and butter, some meat, fish or eggs for older children and at least one pint of milk daily. Any variation of this diet has been noted.

2. Records were made of vitamin D dietary supplements, and the quantities given. Unless. otherwise stated it may be assumed that these additions had been given for at least three months prior to examination.

3. In a certain number of cases information was available concerning the health and diet of the mother during pregnancy. An average diet denotes one meal daily containing meat or fish and vegetables, at least half a pint of milk daily, and eggs two or three times weekly. A toxaemia diet consisted largely of vegetables, fruit, cereals and bread ; milk was usually restricted to the minimum required in tea; eggs, meat, fish and cheese were not allowed, and in some cases butter was also cut out. In some cases the diet has been described as poor due to economic conditions and not on account of any therapeutic restrictions. A poor diet consisted largely of bread and margarine, very little meat or fish, and less than one egg weekly, and little milk, in some cases sweetened condensed being the only milk used. A very good diet contained a pint or more of milk daily, eggs daily, and two cooked meals daily.

4. The home environment of the patients was classified according to opportunities available for exposure to direct sunlight, in the following way:

Very good. Housing estate on the outskirts of 
the city or house with garden in a country district, or outer suburbs.

Good. House with garden in inner suburbs, or flat with easy access to garden in suburbs. (Not basement.)

Fair. House with garden or flat with garden in central areas of city. Basement or top flat with full use of garden in suburbs.

Poor. Central areas with only street or sunless yard.

Bad. Flats or houses with no available space for putting children out to sleep or play.

In some cases no use had been made of good facilities, and these were classed as poor or bad according to the locality of the home.

5. The economic status of the family was known in a few cases and this has been classified as comfort, sufficiency, insufficiency or poverty, using the interpretation of figures for standard needs suggested in the preliminary report of the University of Bristol Social Survey, 1938 (Tout, 1938).

\section{Results}

For the purposes of analysis the children have been divided into three age groups which correspond roughly to the three principal stages of development during the first two years of life. Group 1, from birth to six months represents the stage of milk feeding and the period of most rapid growth. Group 2, from six to twelve months is the period of transition from milk to solid feeding. Group 3, from one to two years represents the stage when solid feeding has been established, when the first dentition is completed and when crawling and walking are well established.

\section{Group I Age 0-6 months}

Three hundred and fifty-eight infants were investigated. A clinical investigation was carried out in every case, and phosphatase was estimated in three hundred and fifty cases. Post-mortem examination of the ribs was possible in fourteen cases and twelve cases were $\mathrm{x}$-rayed. Calcium and phosphorus in serum were estimated in four cases.

Clinical evidence of rickets. One hundred and ninety-nine patients showed no clinical evidence of rickets, i.e. 55.2 per cent. In one hundred and seventy-four of these patients the phosphatase was less than 15 units per c.c. and in the remaining twenty-five cases it was greater than 15 units per c.c., i.e. 12.6 per cent. In addition four cases showing no clinical evidence were not investigated further.

Craniotabes only was found in seven cases. In three of these cases plasma phosphatase was less than 15 units. Slight beading of the ribs only was found in thirty-four with phosphatase less than 15 units and in thirteen patients with increased phosphatase. Two patients in the group that were not investigated further showed slight beading. Therefore 29.5 per cent. of the patients with clinical evidence had mild beading of the ribs only, and of these, $72 \cdot 3$ per cent. had plasma phosphatase below 15 units.

Definite beading of the ribs was present in fifty-five cases or 34.6 per cent. of all cases with evidence of rickets, and in thirty-eight cases the phosphatase was greater than 15 units, i.e. 69 per cent. More severe beading was present in fifteen cases, or 9.4 per cent., and in thirteen of these cases phosphatase was raised above 15 units, i.e. 86.6 per cent. Gross beading was found in six cases or 3.8 per cent. of all positive cases, and phosphatase was raised in five cases.

Craniotabes and beaded ribs were present in twenty-two cases, or 13.8 per cent. of positive cases. All of these patients had phosphatase raised above 15 units.

$\mathrm{X}$-ray evidence. In twelve cases the wrists were x-rayed. Eight of these cases showed positive clinical evidence, but the x-ray was only definitely positive in six cases. The two negative cases had definite and severe beading of the ribs and both had positive phosphatase. The six positive cases all had positive phosphatase, and three of these cases had craniotabes plus beading of the ribs.

Post-mortem evidence. The ribs were examined at post mortem in fourteen cases. In one case clinical examination only had been made with negative results and no evidence was found at post mortem. In four cases with positive clinical and phosphatase test, the post mortem was also positive, and in one case with positive clinical but

TABLE 1A

CORRELATION OF CLINICAL MANIFESTATIONS OF RICKETS WITH PLASMA PHOSPHATASE Group I Age 0-6 months

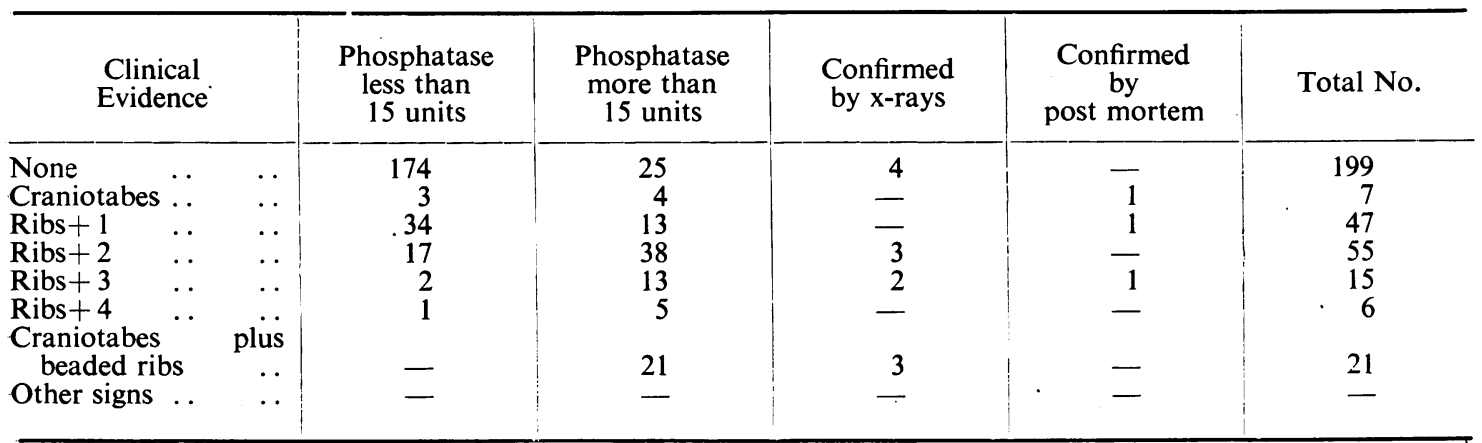


negative phosphatase, the post mortem showed positive evidence in the ribs. The phosphatase in this case was 13 units. In the remaining eight cases there was no evidence of rickets, clinical, phosphatase or post mortem.

Plasma phosphatase. (Tables 1A and 7A.) This investigation was carried out in three hundred and fifty cases. In one hundred and nineteen cases, the phosphatase was raised to 15 units or more, i.e. 34 per cent. Clinical evidence of rickets was found in one hundred and fifty-one cases in which this test had been performed, and there was no clinical evidence in twenty-five cases in which the phosphatase gave a positive result, so that in 62 per cent. of the cases showing clinical evidence of rickets, the phosphatase was raised above 15 units.

It will be seen that in those patients showing only mild clinical evidence of rickets, i.e. beading plus 1 , the phosphatase was raised in only $27 \cdot 7$ per cent. of cases, while 100 per cent. of cases with craniotabes and beaded ribs showed an increase in phosphatase.

TABLE 7A

\section{RANGE OF PLASMA PHOSPHATASE}

(No. of Cases)

\begin{tabular}{|c|c|c|c|c|}
\hline Group & $\begin{array}{l}\text { Below } \\
10 \text { units }\end{array}$ & $\begin{array}{l}10-15 \\
\text { units }\end{array}$ & $\begin{array}{l}15-20 \\
\text { units }\end{array}$ & $\begin{array}{l}\text { Above } \\
20 \text { units }\end{array}$ \\
\hline No evidence ... & 136 & 38 & - & - \\
\hline $\begin{array}{l}\text { Positive clinical } \\
\text { and phospha- } \\
\text { tase .. }\end{array}$ & - & - & 54 & 40 \\
\hline $\begin{array}{l}\text { Positive clinical, } \\
\text { negative phos- } \\
\text { phatase: }\end{array}$ & 20 & 37 & - & - \\
\hline Ribs+ $1 \quad \ldots$ & 12 & 21 & - & - \\
\hline Ribs $+2 \quad \ldots$ & 8 & 16 & - & - \\
\hline $\begin{array}{l}\text { Craniotabes } \\
\text { Negative clinical. }\end{array}$ & - & 3 & - & - \\
\hline $\begin{array}{l}\text { positive phos- } \\
\text { phatase }\end{array}$ & 一 & - & 21 & 4 \\
\hline
\end{tabular}

Analysis of the range of plasma phosphatase results shows that in one hundred and seventy-four patients with no clinical evidence. of rickets, the phosphatase was 10 units or less in 78 per cent., and below 15 units in the remaining 22 per cent. In a further group of twenty-five patients with no clinical evidence, phosphatase range was 15-20 units in 84 per cent., and $20-30$ units in the remaining 16 per cent. In a group of fifty-seven patients with clinical signs of rickets but phosphatase below 15 units, 37 per cent. showed phosphatase values of 10 units or less, and the remainder 10-15 units. Three cases of craniotabes without beading of the ribs were in this latter group, and it may be noted that all the other cases showed mild beading ( 58 per cent.) or definite beading, but none showed marked or gross beading.

In the group of ninety-four patients with clinical evidence and increased phosphatase, fifty-four (55.1 per cent.), showed values from 15-20 units.

\section{Calcium and phosphorus estimations}

These estimations were made in five cases. In all these patients clinical examination and phosphatase test showed evidence of rickets. It may be seen that the calcium: phosphorus product is below 40 in four cases.

\section{Rate of gain in weight}

In one hundred and seventy-four infants with no evidence of rickets, 44.6 per cent. showed an average rate of gain in weight. 35 per cent. showed no gain, loss of weight, or a rate below average. 11.8 per cent. showed a gain above average, and in 0.7 per cent. there were no available data.

In ninety-four infants with positive clinical and chemical evidence, 57.4 per cent. gained at an average rate, $19 \cdot 1$ per cent. were below average, and 17 per cent. were above average. In 8.2 per cent. weights were not available.

In twenty-five patients with positive phosphatase, but no clinical evidence, average rate of gain occurred in 60 per cent. In 20 per cent. the rate was below average, and in 16 per cent. above average. No data were available in 4 per cent.

In fifty-seven patients with clinical evidence of rickets but normal phosphatase values, there was average rate of gain in 61.4 per cent. In 22.8 per cent. rate of gain was below normal, and in 8.7 per cent. above normal. In 7 per cent. there were no available data.

TABLE 8A

CALCIUM AND PHOSPHORUS ESTIMATIONS

\begin{tabular}{|c|c|c|c|c|c|}
\hline Case No. & $\begin{array}{c}\text { Calcium } \\
\text { mgm. per cent. }\end{array}$ & $\begin{array}{l}\text { Phosphorus } \\
\text { mgm. per cent. }\end{array}$ & $\mathrm{Ca} \times \mathbf{P}$ & $\begin{array}{l}\text { Phosphatase } \\
\text { units }\end{array}$ & Clinical \\
\hline 22 & 7 & $5 \cdot 7$ & 39.9 & 15 & $\begin{array}{l}\text { Craniotabes } \\
\text { Severe beading }\end{array}$ \\
\hline 155 & 11 & $3 \cdot 7$ & $40 \cdot 7$ & 50 & $\begin{array}{l}\text { Craniotabes } \\
\text { Ribs plus } 2\end{array}$ \\
\hline 226 & $10 \cdot 7$ & $2 \cdot 4$ & $25 \cdot 7$ & 40 & $\begin{array}{l}\text { Craniotabes } \\
\text { Ribs plus } 3\end{array}$ \\
\hline $\begin{array}{l}259 \\
546\end{array}$ & $\begin{array}{l}8 \cdot 4 \\
9 \cdot 5\end{array}$ & $\begin{array}{l}4 \cdot 75 \\
3 \cdot 5\end{array}$ & $\begin{array}{l}39 \cdot 9 \\
33 \cdot 25\end{array}$ & $\begin{array}{l}24 \cdot 5 \\
18\end{array}$ & $\begin{array}{l}\text { Ribs plus } 3 \\
\text { Craniotabes } \\
\text { Ribs plus } 2\end{array}$ \\
\hline
\end{tabular}


TABLE 3A.-CORRELATION BETWEEN GAIN IN WEIGHT AND MANIFESTATIONS OF RICKETS

\begin{tabular}{|c|c|c|c|c|c|c|}
\hline Gain in weight & $\begin{array}{c}\text { No } \\
\text { evidence }\end{array}$ & $\begin{array}{l}\text { Positive } \\
\text { clinical } \\
\text { and phos- } \\
\text { phatase }\end{array}$ & $\begin{array}{c}\text { Negative } \\
\text { clinical, } \\
\text { positive } \\
\text { phosphatase }\end{array}$ & $\begin{array}{c}\text { Positive } \\
\text { clinical, } \\
\text { negative } \\
\text { phosphatase }\end{array}$ & $\begin{array}{c}\text { Clinical } \\
\text { only }\end{array}$ & Total No. \\
\hline 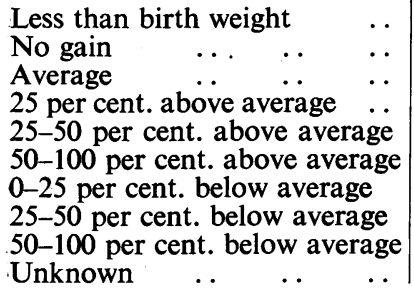 & $\begin{array}{r}8 \\
9 \\
79 \\
11 \\
9 \\
1 \\
19 \\
12 \\
15 \\
11\end{array}$ & $\begin{array}{r}2 \\
4 \\
54 \\
6 \\
7 \\
3 \\
10 \\
1 \\
1 \\
6\end{array}$ & $\begin{array}{r}-2 \\
15 \\
1 \\
3 \\
1 \\
\frac{1}{2} \\
1\end{array}$ & $\begin{array}{r}3 \\
4 \\
35 \\
2 \\
3 \\
1 \\
2 \\
3 \\
4\end{array}$ & $\begin{array}{l}\overline{2} \\
4 \\
\overline{-} \\
\overline{-} \\
\frac{1}{1}\end{array}$ & $\begin{array}{r}13 \\
21 \\
187 \\
20 \\
22 \\
4 \\
31 \\
18 \\
19 \\
23\end{array}$ \\
\hline Total & 174 & 94 & 25 & 57 & 8 & 358 \\
\hline
\end{tabular}

Relationship of severity of disease to occurrence of rickets

TABLE 2A.-TYPES OF SEVERITY OF DISEASE AND CLINICAL SIGNS OF RICKETS

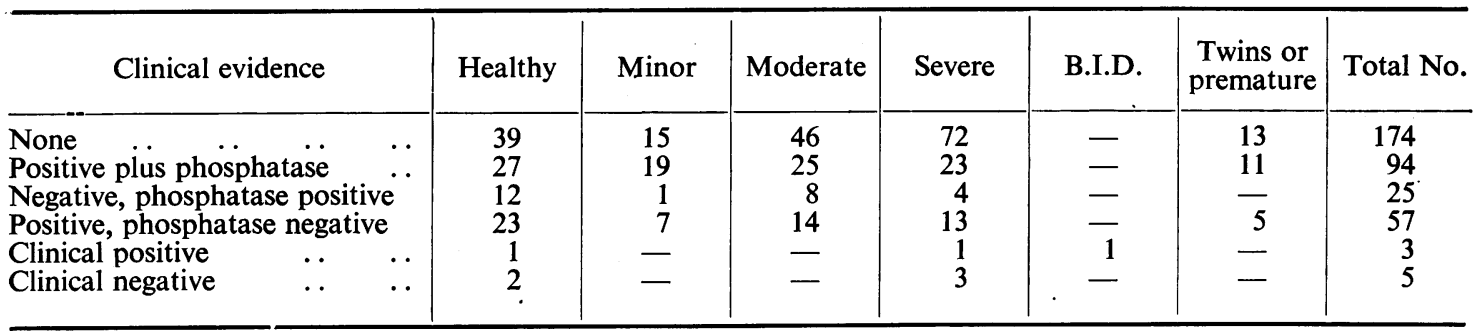

In the group of infants showing no evidence of rickets, 22.4 per cent. were healthy, 8.6 per cent. were suffering from minor ailments, $26 \cdot 4$ per cent. were moderately ill, and $41 \cdot 3$ per cent. were seriously ill. 7 per cent. were twin or premature infants.

Infants with positive clinical and chemical evidence, 28.7 per cent. were healthy, 20.2 per cent. were mildly ill, 26.6 per cent. were moderately ill, and 24.4 per cent. were severely ill. There were 11.7 per cent. twin or premature infants.
Infants with negative clinical evidence and positive phosphatase, 48 per cent. were healthy, 4 per cent. suffered from minor ailments, 32 per cent. were moderately ill, and 16 per cent. were severely ill.

Infants with clinical evidence but negative phosphatase were healthy in 40.3 per cent. of cases, suffered from minor ailments in 12 per cent. and moderate illness in 24.5 per cent. 22 per cent. were severely ill. 8.7 per cent. were twin or premature infants.

Methods of feeding

TABLE 4A.-METHODS OF FEEDING

\begin{tabular}{|c|c|c|c|c|c|c|}
\hline Food & $\begin{array}{c}\text { No } \\
\text { evidence }\end{array}$ & $\begin{array}{c}\text { Positive } \\
\text { clinical } \\
\text { and } \\
\text { phosphatase }\end{array}$ & $\begin{array}{c}\text { Negative } \\
\text { clinical, } \\
\text { positive } \\
\text { phosphatase }\end{array}$ & $\begin{array}{c}\text { Positive } \\
\text { clinical, } \\
\text { negative } \\
\text { phosphatase }\end{array}$ & $\begin{array}{c}\text { Clinical } \\
\text { only }\end{array}$ & $\begin{array}{c}\text { Total } \\
\text { No. }\end{array}$ \\
\hline 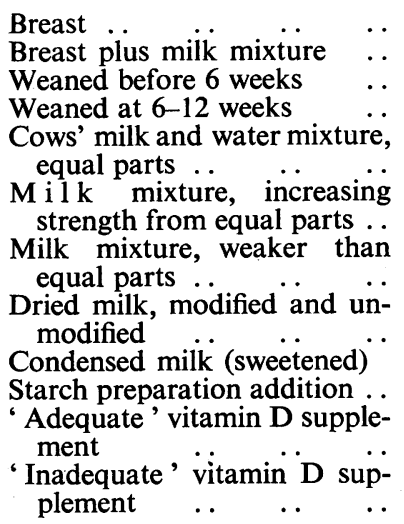 & $\begin{array}{r}67 \\
4 \\
89 \\
11 \\
46 \\
\\
12 \\
3\end{array}$ & $\begin{array}{r}30 \\
2 \\
53 \\
10 \\
\\
22 \\
\\
15 \\
\\
0\end{array}$ & $\begin{array}{r}11 \\
1 \\
12 \\
1 \\
5 \\
\\
0\end{array}$ & $\begin{array}{r}23 \\
2 \\
30 \\
4 \\
12 \\
3 \\
2\end{array}$ & $\begin{array}{l}3 \\
0 \\
5 \\
0 \\
3 \\
1 \\
0\end{array}$ & $\begin{array}{r}134 \\
9 \\
179 \\
26 \\
88\end{array}$ \\
\hline
\end{tabular}


It will be seen (table 4A) that one hundred and thirty-four infants in this group were breast fed at the time of examination, i.e. 37.4 per cent. Sixtyseven (or 50 per cent.) of these infants showed no evidence of rickets. 18 per cent. showed definite rickets, 6.6 per cent. had a positive phosphatase reaction without any clinical evidence, and 13.7 per cent. had some clinical evidence but were negative by other criteria.

Two hundred and twenty-four infants were artificially fed, and one hundred and four ( 46.4 per cent.) showed no evidence of rickets. $28 \cdot 1$ per cent. showed definite rickets, $7 \cdot 1$ per cent. had a positive phosphatase reaction with negative clinical signs, and 13.9 per cent. showed clinical signs only, with negative phosphatase. It will be noticed that 50 per cent. of the infants were weaned before the sixth week of life, and $7 \cdot 2$ per cent. were weaned before the fourth month, 39 per cent. of the artificially fed infants were being fed on a cows' milk and water mixture, equal parts, and 25 per cent. of these infants showed definite evidence of rickets. $13 \cdot 8$ per cent. were receiving a stronger milk mixture, but 50 per cent. of this group showed definite evidence of rickets. Only five infants were fed on a weaker mixture.

Sixty infants were receiving dried milks, full and half cream, of various brands; 30 per cent. of these infants showed positive evidence of rickets, and 43 per cent. were definitely negative.

Twenty-one infants were fed on sweetened condensed milk, and 25 per cent. of these infants were positive. Thirteen infants were fed on cows' milk mixture with a starch or cereal addition.

Only fifty-two infants were receiving any vitamin $\mathrm{D}$ supplement, which included cod-liver oil, cod-liver oil emulsion, halibut oil, virol, butter added to feeds, or vitamin concentrates. An adsquate dose was considered to be approximately 400 units daily.

Maternal diet during pregnancy

TABLE 5A.-MATERNAL DIET DURING PREGNANCY

\begin{tabular}{|c|c|c|c|c|c|c|c|}
\hline Diet & & $\begin{array}{c}\text { No } \\
\text { evidence }\end{array}$ & $\begin{array}{c}\text { Positive } \\
\text { clinical } \\
\text { and } \\
\text { phosphatase }\end{array}$ & $\begin{array}{c}\text { Negative } \\
\text { clinical, } \\
\text { positive } \\
\text { phosphatase }\end{array}$ & $\begin{array}{c}\text { Positive } \\
\text { clinical, } \\
\text { negative } \\
\text { phosphatase }\end{array}$ & $\begin{array}{c}\text { Clinical } \\
\text { only }\end{array}$ & Total No. \\
\hline $\begin{array}{lll}\text { Very good } & \ldots & \ldots \\
\text { Average } & \ldots & \ldots \\
\text { Poor } & \ldots & \ldots \\
\text { Toxaemia } & \text {. } & \text {. } \\
\text { Vitamin D supplements }\end{array}$ & \begin{tabular}{l|}
$\ldots$ \\
$\ldots$ \\
$\ldots$ \\
$\ldots$ \\
$\ldots$
\end{tabular} & $\begin{array}{r}19 \\
53 \\
14 \\
13 \\
5\end{array}$ & $\begin{array}{r}8 \\
32 \\
15 \\
11 \\
1\end{array}$ & $\begin{array}{l}3 \\
8 \\
6 \\
2 \\
2\end{array}$ & $\begin{array}{r}5 \\
12 \\
17 \\
4 \\
2\end{array}$ & $\begin{array}{l}2 \\
5 \\
- \\
-\end{array}$ & $\begin{array}{r}37 \\
110 \\
52 \\
30 \\
10\end{array}$ \\
\hline \multicolumn{2}{|c|}{ Total .. } & 104 & 67 & 21 & 40 & 7 & 239 \\
\hline
\end{tabular}

Two hundred and thirty-nine mothers were able to give information as to diet during pregnancy. 46 per cent. of these patients had an average diet, 15.5 per cent. had a very good diet, and 12.5 per cent. had a toxaemia of pregnancy treated with a carbohydrate diet. 21.75 per cent. had a poor diet from economic reasons. Only 4 per cent. had vitamin D supplements.
51 per cent. of infants from the mothers who had a very good diet showed no evidence of rickets. 48 per cent. showed no evidence where the antenatal diet was average. 27 per cent. showed no evidence where the maternal diet was poor, and 43 per cent. showed no evidence when toxaemia had been present.

Environment

TABLE 6A.-ECONOMIC STATUS OF THE FAMILY AND ENVIRONMENT

\begin{tabular}{|c|c|c|c|c|c|c|c|c|}
\hline \multicolumn{3}{|c|}{$\begin{array}{l}\text { Status }(1-4) \text { and } \\
\text { environment }(5-9)\end{array}$} & $\begin{array}{c}\text { No } \\
\text { evidence }\end{array}$ & $\begin{array}{c}\text { Positive } \\
\text { clinical } \\
\text { and } \\
\text { phosphatase }\end{array}$ & $\begin{array}{c}\text { Negative } \\
\text { clinical, } \\
\text { positive } \\
\text { phosphatase }\end{array}$ & $\begin{array}{c}\text { Positive } \\
\text { clinical, } \\
\text { negative } \\
\text { phosphatase }\end{array}$ & $\begin{array}{l}\text { Clinical } \\
\text { only }\end{array}$ & Total No. \\
\hline $\begin{array}{l}\text { 1. Comfort } \\
\text { 2. Sufficiency } \\
\text { 3. Insufficiency } \\
\text { 4. Poverty } \\
\text { 5. Very good } \\
\text { 6. Go } \\
\text { 6. Good } \\
\text { 7. Fair } \\
\text { 8. Poor } \\
\text { 9. Bad }\end{array}$ & $\begin{array}{l}\cdots \\
\cdots \\
\cdots \\
\cdots \\
\cdots \\
\cdots \\
\cdots \\
\cdots\end{array}$ & $\begin{array}{l}\ldots \\
\cdots \\
\ldots \\
\cdots \\
\ldots \\
\cdots \\
\cdots \\
\cdots\end{array}$ & $\begin{array}{r}3 \\
9 \\
6 \\
14 \\
36 \\
54 \\
37 \\
27 \\
20\end{array}$ & $\begin{array}{r}3 \\
10 \\
9 \\
9 \\
15 \\
23 \\
27 \\
20 \\
8\end{array}$ & $\begin{array}{l}-1 \\
9 \\
6 \\
7 \\
3 \\
4 \\
5\end{array}$ & $\begin{array}{r}- \\
6 \\
4 \\
9 \\
10 \\
10 \\
13 \\
16 \\
8\end{array}$ & $\begin{array}{l}\frac{1}{1} \\
-1 \\
1 \\
3 \\
2 \\
-\end{array}$ & $\begin{array}{l}7 \\
26 \\
20 \\
41 \\
68 \\
95 \\
83 \\
69 \\
41\end{array}$ \\
\hline
\end{tabular}


19 per cent. of the patients lived in very good surroundings with regard to sunlight. In this group, 53 per cent. showed no evidence of rickets.

26.5 per cent. lived in a good environment, of whom 57.8 per cent. showed no evidence.

23.2 per cent. lived in a fair environment, of whom 44.5 per cent. showed no evidence.

19 per cent. lived in a poor environment, of whom 38.9 per cent. showed no evidence.

11.4 per cent. lived in a bad environment, of whom 50 per cent. showed no evidence of rickets.

Economic status. The economic status of ninetyfour patients was known. $7 \cdot 4$ per cent. were living in comfort, of whom 43 per cent. had no evidence of rickets.

27.6 per cent. had sufficiency, of whom 34.6 per cent. showed no evidence of rickets.

21 per cent. had insufficiency, of whom 30 per cent. showed no evidence of rickets.

44.8 per cent. were living in poverty (i.e. 11.4 per cent. of all the infants in this age group), and 34 per cent. of these infants showed no evidence of rickets.

Correlation of age and manifestations of rickets. In this group, thirty-one patients were below one month old, of whom 66 per cent. showed no evidence: of rickets.

One hundred and twenty-five patients were aged one to two months, of whom 53.6 per cent. showed no evidence of rickets, 18 per cent. showed definite evidence.

Eighty-four patients were aged two to three months, of whom 50 per cent. showed no evidence and 29.6 per cent. showed definite evidence.

Fifty-three patients were aged three to four months of whom 43 per cent. showed no evidence and 33.9 per cent. showed definite evidence.

Fifty-five patients were aged four to five months, of whom 40 per cent. showed no evidence, and $47 \cdot 4$ per cent. showed definite evidence.

\section{Group II. Age 6-12 months}

There were one hundred and eighty-eight infants in this group. A clinical examination was carried out in every case, and phosphatase was estimated in one hundred and eighty-six patients. Post-mortem findings were available in five cases. Thirty-nine infants were $x$-rayed. Blood calcium and phosphorus estimations were made in three cases.

TABLE 1B

CORRELATION OF CLINICAL MANIFESTATIONS OF RICKETS WITH PLASMA PHOSPHATASE

\begin{tabular}{|c|c|c|c|c|c|}
\hline Clinical evidence & $\begin{array}{l}\text { Phosphatase } \\
\text { less than }\end{array}$ & $\begin{array}{l}\text { Phosphatase } \\
\text { more than }\end{array}$ & $\begin{array}{c}\text { Confirmed by } \\
\text { X-rays }\end{array}$ & $\begin{array}{l}\text { Confirmed by } \\
\text { post mortem }\end{array}$ & Total No. \\
\hline $\begin{array}{lll}\text { None } & \ldots & \ldots \\
\text { Craniotabes } & \ldots & \\
\text { Ribs+1 } & \ldots & \ldots \\
\text { Ribs+2 } & \ldots & \ldots \\
\text { Ribs }+3 & \ldots & \ldots \\
\text { Ribs+4 } & \ldots & \ldots \\
\begin{array}{l}\text { Other signs } \\
\text { Craniotabes }\end{array} & \ldots & \text { plus } \\
\text { beading } & \ldots & \ldots\end{array}$ & $\begin{array}{r}93 \\
24 \\
6 \\
-1 \\
- \\
-\end{array}$ & $\begin{array}{r}5 \\
5 \\
23 \\
17 \\
5 \\
3 \\
4\end{array}$ & $\begin{array}{r}7 \\
3 \\
8 \\
13 \\
3 \\
2 \\
3\end{array}$ & $\begin{array}{l}2 \\
1 \\
1 \\
- \\
-\end{array}$ & $\begin{array}{r}98 \\
29 \\
29 \\
17 \\
6 \\
3\end{array}$ \\
\hline
\end{tabular}

Clinical evidence of rickets. No clinical evidence of rickets was found in ninety-eight patients, i.e. $52 \cdot 1$ per cent. The plasma phosphatase was less than 15 units in ninety-three of these patients, and in $5 \cdot 2$ per cent. it was above 15 units.

In the remaining ninety patients, slight beading of the ribs only was found in twenty-nine (32 per cent.), definite beading was present in twenty-nine (32 per cent.), more severe beading was present in seventeen cases ( 20 per cent.), and gross beading in six cases, (6.66 per cent.).

Craniotabes alone was not present in any case, but four patients showed craniotabes and beading of the ribs ( 4.4 per cent.). Other signs of rickets were also present in three cases.

Phosphatase was less than 15 units in twenty-four cases with mild beading, i.e. $82 \cdot 7$ per cent.

In cases showing definite beading, phosphatase was increased above 15 units in 79 per cent., and in all cases of marked beading. It was not above
15 units in one case of gross beading (16.6 per cent.), but it was raised in all cases with craniotabes.

Tetany was present in one case.

$\mathbf{X}$-ray evidence. Thirty-nine cases were X-rayed. In seven cases there was no clinical or $x$-ray evidence of rickets. In twenty-eight cases there was positive clinical, phosphatase and x-ray evidence of rickets. One case showed mild beading of the ribs, with phosphatase increased to 15 units and a doubtfully positive $x$-ray. One case with definite beading of the ribs had no x-ray evidence in the wrists and the phosphatase was 12 units.

Post-mortem evidence Post-mortem findings were available in five patients. In two cases no evidence of rickets was found and this confirmed the clinical findings. In both cases phosphatase was 10 units or less. In one case with mild beading of the ribs, phosphatase and post mortem showed no evidence. Definite post-mortem evidence was found in two cases with positive clinical and phosphatase findings. 
Plasma phosphatase

TABLE 7B

RANGE OF PLASMA PHOSPHATASE

(Figures refer to number of cases)

\begin{tabular}{|c|c|c|c|c|}
\hline Group & $\begin{array}{l}\text { Below } \\
10 \text { units }\end{array}$ & $\begin{array}{l}10-15 \\
\text { units }\end{array}$ & $\begin{array}{l}15-20 \\
\text { units }\end{array}$ & $\begin{array}{l}\text { Above } \\
20 \text { units }\end{array}$ \\
\hline $\begin{array}{l}\text { No evidence } \\
\text { Positive clinical } \\
\text { and phospha- }\end{array}$ & 70 & 23 & - & - \\
\hline $\begin{array}{l}\text { tase } \\
\text { Positive clinical, }\end{array}$ & - & - & 33 & 24 \\
\hline $\begin{array}{l}\text { negative phos- } \\
\text { phatase: }\end{array}$ & 12 & 19 & - & - \\
\hline $\begin{array}{ll}\text { Ribs+1 } & \ldots\end{array}$ & 10 & 14 & - & - \\
\hline $\begin{array}{ll}\text { Ribs+2 } & \ldots \\
\text { Ribs+4 } & \ldots\end{array}$ & 2 & $\begin{array}{l}4 \\
1\end{array}$ & 二 & 二 \\
\hline $\begin{array}{l}\text { Negative clinical, } \\
\text { positive phos- } \\
\text { phatase }\end{array}$ & & - & 5 & - \\
\hline
\end{tabular}

This investigation was carried out in one hundred and eighty-six patients. In fifty-seven patients the plasma phosphatase was above 15 units, i.e. $30 \cdot 6$ per cent., and there were also clinical signs of rickets, and in a further five patients there was no clinical evidence but the phosphatase was raised to 15 units or more. In thirty-one cases with clinical evidence of rickets the phosphatase was below 15 units, so that in eighty-eight patients with signs suggestive of rickets, phosphatase was increased in 64.7 per cent.

In the group of patients with mild beading of the ribs as the only clinical sign of rickets, the phosphatase was less than 15 units in 82 per cent. of cases.

Analysis of the range of plasma phosphatase results shows that in ninety-three patients with no evidence of rickets, the phosphatase was 10 units or less in 74.6 per cent., and in the remaining 25.4 per cent. it was 10-15 units. In a further group of patients with no clinical evidence, the phosphatase was 15-20 units in all five patients.

Fifty-seven patients with clinical evidence of rickets showed phosphatase values of 15-20 units in 58 per cent., and above 20 units in the remainder.

Thirty-one patients with clinical evidence of rickets had phosphatase values below 10 units in twelve cases (38.7 per cent.), and 10-15 units in the remainder. 83 per cent. of the cases with phosphatase below 10 units showed slight beading of the ribs only, in the other cases there was definite beading. Where the phosphatase was 10-15 units, fourteen cases ( 73 per cent.) showed slight beading, and one case showed gross beading of the ribs. There were no cases of craniotabes in this group.

In this age group only three patients had craniotabes, and in all these the phosphatase was raised.

\section{Calcium and phosphorus estimations}

TABLE 8B.-CALCIUM AND PHOSPHORUS ESTIMATIONS

\begin{tabular}{c|c|c|c|c|c}
\hline Case No. & $\begin{array}{c}\text { Calcium } \\
\text { mgm. per cent. }\end{array}$ & $\begin{array}{c}\text { Phosphorus } \\
\text { mgm. per cent. }\end{array}$ & Ca $\times \mathbf{P}$ & $\begin{array}{c}\text { Phosphatase } \\
\text { units }\end{array}$ & Clinical \\
\hline 430 & $\begin{array}{c}9 \cdot 9 \\
11 \cdot 2\end{array}$ & 5 & $49 \cdot 5$ & 10 & $\begin{array}{c}\text { No evidence } \\
\text { No evidence } \\
\text { Tetany, craniotabes, } \\
\text { ribs }+3\end{array}$ \\
\hline
\end{tabular}

Blood calcium and phosphorus was estimated in three cases. In two of these there were no clinical or radiological evidence of rickets, but the infants had convulsions. In both cases the calcium and phosphorus product was well above forty, and the phosphatase below 12 units. In the third case the infant had craniotabes, tetany and severe beading of the ribs and a marked lowering of the blood calcium was found. The phosphatase in this case was 27 units.

\section{Rate of gain in weight}

TABLE 3B.-CORRELATION BETWEEN GAIN IN WEIGHT AND MANIFESTATIONS OF RICKETS

\begin{tabular}{|c|c|c|c|c|c|c|}
\hline Gain in weight & $\begin{array}{c}\text { No } \\
\text { evidence }\end{array}$ & $\begin{array}{c}\text { Positive } \\
\text { clinical } \\
\text { and } \\
\text { phosphatase }\end{array}$ & $\begin{array}{c}\text { Negative } \\
\text { clinical, } \\
\text { positive } \\
\text { phosphatase }\end{array}$ & $\begin{array}{c}\text { Positive } \\
\text { clinical, } \\
\text { negative } \\
\text { phosphatase }\end{array}$ & $\begin{array}{c}\text { Clinical } \\
\text { only }\end{array}$ & Total No. \\
\hline $\begin{array}{l}\text { Less than birth weight } \\
\text { No gain } \quad . . \\
\text { Average } \quad . . \\
0-25 \text { per cent. above average } \\
25-50 \text { per cent. above average } \\
50-100 \text { per cent. above average } \\
0-25 \text { per cent. below average } \\
25-50 \text { per cent. below average } \\
50-100 \text { per cent. below average }\end{array}$ & $\begin{array}{r}- \\
1 \\
54 \\
10 \\
1 \\
3 \\
13 \\
4 \\
7\end{array}$ & $\begin{array}{r}- \\
36 \\
6 \\
1 \\
1 \\
5 \\
1 \\
7\end{array}$ & $\begin{array}{l}- \\
- \\
- \\
- \\
-\end{array}$ & $\begin{array}{r}- \\
\overline{19} \\
3 \\
1 \\
\frac{1}{2} \\
2 \\
5\end{array}$ & $\begin{array}{l}- \\
- \\
- \\
- \\
-\end{array}$ & $\begin{array}{r}-1 \\
115 \\
19 \\
3 \\
4 \\
19 \\
8 \\
19\end{array}$ \\
\hline
\end{tabular}


In ninety-three infants with no evidence of rickets, 58 per cent. showed an average rate of gain in weight; 26.9 per cent. showed either no gain or less than average gain; 15 per cent. showed a gain above average.

In fifty-seven infants with definite evidence of rickets, 63 per cent. gained weight at an average rate, 22.8 per cent. were below average, and 14 per cent. were above average.

In five infants with no clinical evidence of rickets but with an increased phosphatase, 80 per cent. showed an average rate of gain and the remaining patient was below average.

In thirty-one patients with some clinical evidence but normal phosphatase values, 61.3 per cent. showed an average rate of gain, 12.9 per cent. were above average.

Two patients with clinical evidence who were not investigated further both showed an average rate of gain.

Relationship of severity of disease to occurrence of rickets

TABLE 2B.-SEVERITY OF DISEASE AND CLINICAL SIGNS OF RICKETS

\begin{tabular}{|c|c|c|c|c|c|c|}
\hline Clinical evidence & Healthy & Minor & Moderate & Severe & $\begin{array}{l}\text { Twin or } \\
\text { premature }\end{array}$ & Total No. \\
\hline 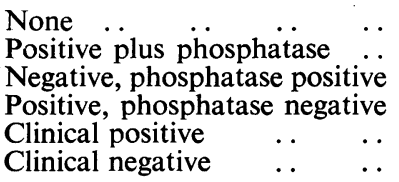 & $\begin{array}{r}5 \\
7 \\
-1 \\
-\end{array}$ & $\begin{array}{r}23 \\
8 \\
3 \\
2 \\
- \\
-\end{array}$ & $\begin{array}{r}39 \\
23 \\
13 \\
2 \\
-\end{array}$ & $\begin{array}{r}28 \\
19 \\
2 \\
15 \\
- \\
-\end{array}$ & $\begin{array}{r}9 \\
2 \\
-1 \\
-\end{array}$ & $\begin{array}{r}93 \\
57 \\
5 \\
31 \\
2 \\
-\end{array}$ \\
\hline
\end{tabular}

5.4 per cent. of the group of ninety-three infants showing no evidence of rickets were healthy. 24.7 per cent. of this group were suffering from minor ailments, 41.9 per cent. were moderately ill, and $30 \cdot 1$ per cent. severely ill. There were nine twin or premature infants, i.e. $9 \cdot 6$ per cent.

12.3 per cent. of the infants showing definite clinical and biochemical evidence of rickets were healthy. 14 per cent. of this group had minor ailments, $40 \cdot 3$ per cent. were moderately ill, and 33.3 per cent. severely ill. 3.5 per cent. were twin or premature infants.
Of the five cases with no clinical evidence but increased phosphatase, 60 per cent. had minor ailments and 40 per cent. were moderately ill. There were no twin or premature cases.

$3 \cdot 2$ per cent. of infants with clinical signs of rickets and low plasma phosphatase were healthy. 6.4 per cent. had minor ailments, 41.9 per cent. were moderately ill, $48 \cdot 7$ per cent. were severely ill. There was one twin infant, i.e. $3 \cdot 3$ per cent.

Both cases in which clinical investigation only was carried out were moderately ill.

\section{Methods of feeding}

TABLE 4B.-METHODS OF FEEDING

\begin{tabular}{|c|c|c|c|c|c|c|}
\hline Food & $\begin{array}{c}\text { No } \\
\text { evidence }\end{array}$ & $\begin{array}{c}\text { Positive } \\
\text { clinical } \\
\text { and } \\
\text { phosphatase }\end{array}$ & $\begin{array}{c}\text { Negative } \\
\text { clinical, } \\
\text { positive } \\
\text { phosphatase }\end{array}$ & $\begin{array}{c}\text { Positive } \\
\text { clinical, } \\
\text { negative } \\
\text { phosphatase }\end{array}$ & $\begin{array}{c}\text { Clinical } \\
\text { only }\end{array}$ & Total No. \\
\hline 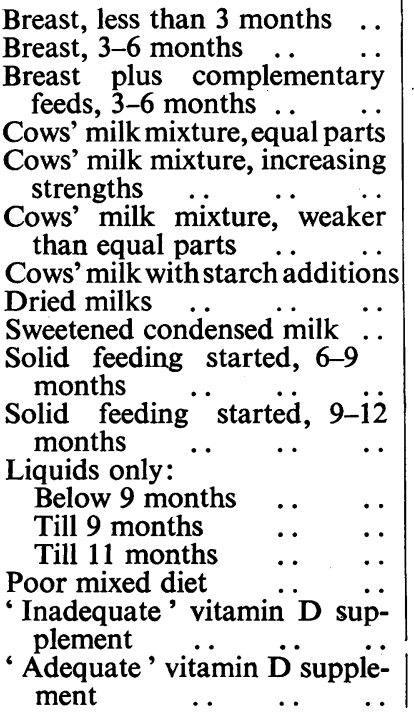 & $\begin{array}{l}-\overline{10} \\
16 \\
2 \\
31 \\
6\end{array}$ & $\begin{array}{r}31 . \\
26 \\
\overline{10} \\
\\
15 \\
- \\
4 \\
10 \\
3 \\
25 \\
2 \\
23 \\
7 \\
1 \\
\end{array}$ & $\begin{array}{r}3 \\
2 \\
-1 \\
3 \\
- \\
- \\
- \\
- \\
2 \\
- \\
2 \\
- \\
- \\
1\end{array}$ & $\begin{array}{r}18 \\
13 \\
-9 \\
4 \\
-6 \\
3 \\
3 \\
14 \\
-\end{array}$ & $\begin{array}{l}1 \\
-1 \\
- \\
- \\
- \\
- \\
- \\
-\end{array}$ & $\begin{array}{r}\overline{39} \\
40 \\
-\overline{20} \\
29 \\
8 \\
73 \\
8\end{array}$ \\
\hline
\end{tabular}


In this age group, ninety-one infants were on liquid feeds only at the time of examination, i.e. 48.4 per cent. Twenty-six infants were on liquids only until nine months old, and two infants were still on liquids only at eleven months. In most cases cereal additions and vegetables and whole cows' milk formed the usual mixed diet. One infant was still on sweetened condensed milk only at eleven months. One hundred and three infants were breast fed for less than three months (54.8 per cent.), sixty-three infants were breast fed longer than three months (33 per cent.). Complementary feeding was not used in any case after three months. 41 per cent. of the infants breast fed for longer than three months showed definite evidence of rickets, and 20.6 per cent. had some clinical evidence with negative phosphatase. Two infants showed no clinical evidence, but phosphatase was increased.

Thirty-nine infants were fed on cows' milk and water mixture, equal parts. Of these, 25 per cent. showed definite evidence of rickets, and there was clinical evidence with low phosphatase in 23 per cent. One case had an increased phosphatase value with no clinical evidence.

Forty infants were fed on cows' milk mixture stronger than equal parts of milk and water. 37.5 per cent. showed positive evidence of rickets, 45 per cent. showed no evidence, 10 per cent. had clinical signs with low phosphatase, and 7.5 per cent. had increased phosphatase with no clinical signs.
Twenty infants were receiving starch preparations added to cows' milk. 20 per cent. of these showed definite evidence of rickets, 30 per cent. showed some clinical evidence only. 50 per cent. showed no evidence.

Twenty-nine infants were fed on dried milks, 55 per cent. of these showed no evidence of rickets. 37.9 per cent. showed definite evidence of rickets. $10 \cdot 3$ per cent. showed clinical evidence with negative phosphatase.

Eight infants were fed on sweetened condensed milk. 25 per cent. of these showed no evidence of rickets. 37.5 per cent. showed definite evidence of rickets, and 37.5 per cent. showed clinical signs with normal phosphatase.

Seventy-three infants ( $38^{\circ}$ per cent.) were having some mixed feeding before the age of nine months.

Sixty-five infants received some additional vitamin $\mathrm{D}$ containing preparation. This was inadequate in 52.3 per cent. 38 per cent. showed no evidence of rickets in infants in whom the supplement was inadequate, and 33 per cent. showed definite evidence of rickets, a further 23 per cent. showed clinical signs only, and one case had a raised phosphatase only. When the supplement was adequate, $54 \cdot 8$ per cent. of patients showed no evidence of rickets, and 32 per cent. showed definite evidence. 12.9 per cent. had increased phosphatase without clinical signs.

Maternal diet during pregnancy

TABLE 5B.-MATERNAL DIET DURING PREGNANCY

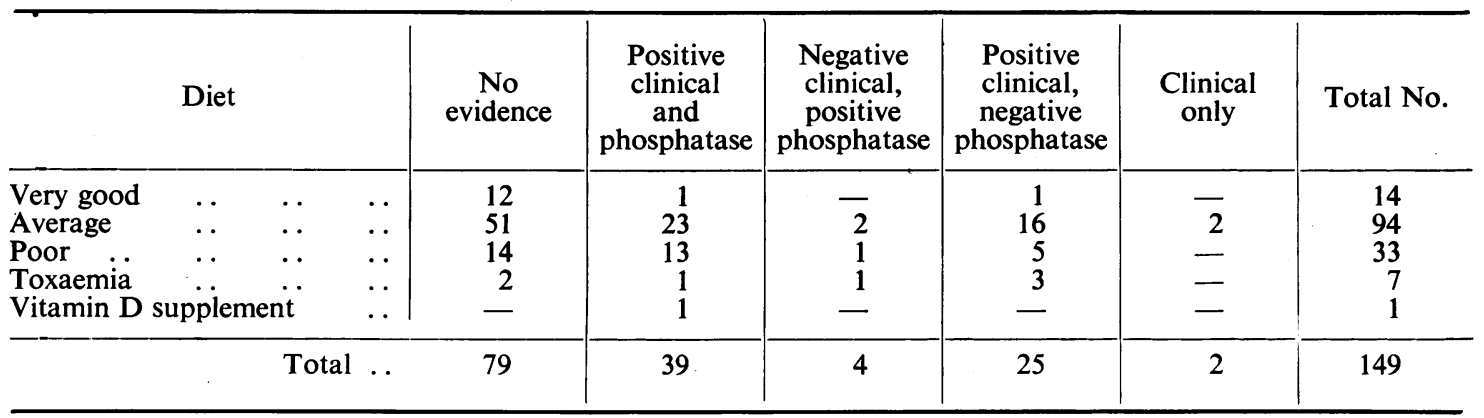

Information concerning diet of the mother during pregnancy was available in one hundred and fortynine cases.

In 62 per cent. of cases the diet was average. In 9 per cent. the diet was very good, and in 22 per cent. it was poor. 4.7 per cent. had toxaemia of pregnancy with a carbohydrate type of diet. Only one patient had vitamin D supplement.

85.7 per cent. of the patients showed no evidence of rickets where the mother's diet was very good. 54.2 per cent. of the patients showed no evidence where the maternal diet had been average. 42.4 per cent. showed no evidence where the maternal diet was poor. Only two infants from the toxaemic mothers showed no evidence, i.e. $28 \cdot 5$ per cent.

\section{Environment}

29.2 per cent. of the patients came from a very good environment. 56.3 per cent. of these showed no evidence of rickets.

21.9 per cent. came from a good environment. 51 per cent. of these showed no evidence of rickets.

22.3 per cent. came from a fair environment, and 50 per cent. of these showed no evidence of rickets.

22.3 per cent. came from a poor environment, and 42.8 per cent. showed no evidence of rickets.

5.8 per cent. came from a bad environment, and 18 per cent. showed no evidence of rickets.

Economic status. The economic status of fiftynine patients in this group was known. Eight patients were living in comfort, of whom three 
TABLe 6B

ECONOMIC STATUS OF THE FAMILY AND ENVIRONMENT

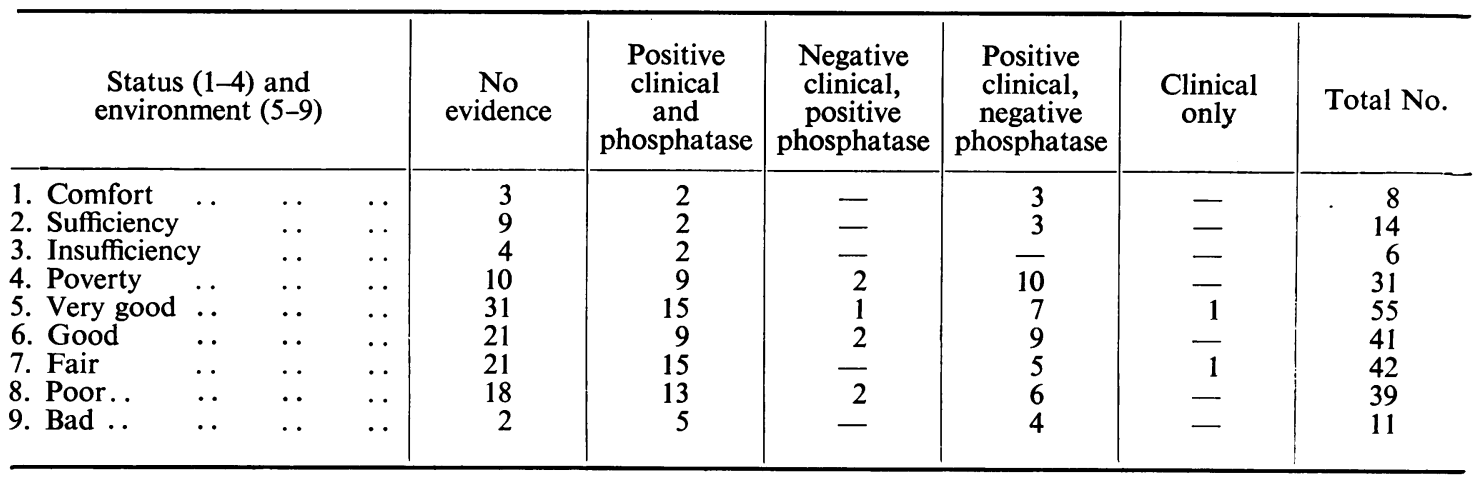

showed no evidence of rickets, and three showed clinical evidence only. Fourteen patients had sufficiency, of whom nine (64 per cent.) showed no evidence of rickets. Six patients had insufficiency of whom four showed no evidence, and 31 were living in poverty, of whom ten ( 33 per cent.) showed no evidence.

Correlation of age and manifestations of rickets. In this age group, thirty-six patients were aged six months, of whom 52.7 per cent. showed no evidence of rickets.

Thirty-one patients were aged seven months, of whom 54.8 per cent. showed no evidence of rickets.

Thirty-five patients were aged eight months, of whom $45 \cdot 7$ per cent. showed no evidence of rickets.
Thirty-five patients were aged nine months, of whom 57 per cent. showed no evidence of rickets.

Twenty-two patients were aged ten months, of whom 40.9 per cent. showed no evidence of rickets.

Twenty-nine patients were aged eleven months, of whom 41 per cent. showed no evidence of rickets.

\section{Group III. Age 1-2 years}

There were two hundred and seventy-four children in this group. A clinical examination was carried out in every case, and phosphatase was estimated in two hundred and sixty-two cases. Post-mortem findings were available in one case. Sixty-eight infants were x-rayed. Calcium and phosphorus. were estimated in five cases.

TABLE 1C

CORRELATION OF CLINICAL MANIFESTATIONS OF RICKETS WITH PLASMA PHOSPHATASE

\begin{tabular}{|c|c|c|c|c|c|}
\hline Clinical evidence & $\begin{array}{c}\text { Phosphatase } \\
\text { less than } \\
15 \text { units }\end{array}$ & $\begin{array}{l}\text { Phosphatase } \\
\text { above } 15 \text { units }\end{array}$ & $\begin{array}{c}\text { Confirmed by } \\
\text { x-rays }\end{array}$ & $\begin{array}{l}\text { Confirmed by } \\
\text { post mortem }\end{array}$ & Total No. \\
\hline $\begin{array}{lll}\text { None } & \ldots & \ldots \\
\text { Craniotabes } & & \ldots \\
\text { Ribs }+1 & \ldots & \ldots \\
\text { Ribs }+2 & \ldots & \ldots \\
\text { Ribs }+3 & \ldots & \ldots \\
\text { Ribs }+4 & \ldots & \ldots \\
\text { Other signs } & \ldots & \ldots \\
\text { Cr a n i o t a bes } & \text { plus } \\
\text { beaded ribs } & \ldots\end{array}$ & $\begin{array}{r}\frac{146}{22} \\
- \\
- \\
-\end{array}$ & $\begin{array}{r}\frac{2}{11} \\
22 \\
15 \\
3 \\
30 \\
2\end{array}$ & $\begin{array}{r}22 \\
7 \\
11 \\
8 \\
2 \\
16 \\
2\end{array}$ & $\begin{array}{l}1 \\
- \\
- \\
- \\
-\end{array}$ & $\begin{array}{r}156 \\
40 \\
26 \\
15 \\
3 \\
35 \\
2\end{array}$ \\
\hline
\end{tabular}

Clinical evidence of rickets. No clinical evidence of rickets was found in one hundred and fifty-six patients, i.e. $\mathbf{5 7 \cdot 2}$ per cent. The plasma phosphatase was estimated in one hundred and forty-six of these patients and was below 15 units. In two further cases, with no evidence, it was above 15 units.

In the remaining one hundred and fifteen patients slight beading of the ribs only was found in forty patients ( 34.8 per cent.), definite beading was found in twenty-six cases ( 22.6 per cent.), marked beading was present in fifteen cases (13 per cent.), and severe beading in three cases, i.e. $2 \cdot 6$ per cent. Thirtyfive cases showed some other signs of rickets, which were bow-legs or genu valgum, i.e. 30.4 per cent. Craniotabes was only found in two patients $(1.7$ per cent.), and in both of these patients there were other signs of rickets.

Plasma phosphatase was less than 15 units in twenty-two cases with mild beading (19 per cent.), in four cases with definite beading (3.04 per cent.) and in five cases with other signs of rickets in addition.

Phosphatase was above 15 units in eighty-three cases (72 per cent.), and in all cases with marked or gross beading and with craniotabes.

In three cases there was no clinical evidence of rickets and no further investigations were done. 
$\mathrm{X}$-ray evidence. Sixty-eight patients were $\mathrm{X}$-rayed. In twenty-two patients there was no clinical or $\mathrm{x}$-ray evidence of rickets. In fourteen of these cases the phosphatase was also negative.

Six patients had some clinical signs of rickets but the phosphatase was below 15 units and the x-ray showed no definite evidence.

In the other forty patients the x-ray confirmed the clinical diagnosis of rickets and in thirteen cases with negative phosphatase, the appearances were those of healed rickets.

Post-mortem evidence Post-mortem findings were only available in one case which had no clinical or phosphatase evidence of rickets.

Plasma phosphatase

TABLE 7c
RANGE OF PLASMA PHOSPHATASE.

\begin{tabular}{|c|c|c|c|c|}
\hline Group & $\begin{array}{c}\text { Below } \\
10 \text { units }\end{array}$ & $\begin{array}{l}10-15 \\
\text { units }\end{array}$ & $\begin{array}{l}15-20 \\
\text { units }\end{array}$ & $\begin{array}{l}\text { Above } \\
20 \text { units }\end{array}$ \\
\hline $\begin{array}{l}\text { No evidence } \\
\text { Positive clinical } \\
\text { and phospha- } \\
\text { tase } \\
\text {.. } \quad . .\end{array}$ & $\begin{array}{r}- \\
\begin{array}{r}\text { X-ra } \\
\text { pos } \\
\text { (heale }\end{array}\end{array}$ & $\begin{array}{cc}29 \\
\\
\text { y } \\
\text { d) } \\
\text { d) } \\
\text { d) pos. }\end{array}$ & 2 & - \\
\hline $\begin{array}{l}\text { Positive clinical, } \\
\text { negative phos- } \\
\text { phatase: } \\
\text { Ribs }+1 \\
\text { Ribs }+2 \quad \ldots \\
\text { Ribs }+3 \quad \ldots \\
\text { Ribs }+4 \quad \ldots \\
\text { Craniotabes } . \\
\text { Other signs } \\
\text { Phosphatase only } \\
\text { positive } \quad . .\end{array}$ & $\begin{array}{l}19 \\
14 \\
3 \\
- \\
\frac{7}{2} \\
-\end{array} \mid$ & $\begin{array}{l}13 \\
10 \\
2 \\
- \\
- \\
1\end{array}$ & $\begin{array}{l}- \\
= \\
=\end{array}$ & $\begin{array}{l}- \\
= \\
= \\
=\end{array}$ \\
\hline
\end{tabular}

This investigation was carried out in two hundred and sixty-one patients.
In sixty-nine patients the phosphatase was 15 units or higher, i.e. 26.6 per cent., and there were clinical signs of rickets in every case. In forty-three patients there were clinical signs of rickets but the phosphatase was below 15 units. (16.6 per cent.). In two cases there was no clinical evidence but phosphatase was 15 units or above.

Therefore in the hundred and twelve patients with clinical signs of rickets, phosphatase was increased above 15 units in 61.07 per cent.

In the group of patients with mild beading of the ribs as the only sign of rickets, phosphatase was increased in 33 per cent. In patients with marked or gross beading or craniotabes, phosphatase was increased in every case, and in those cases with definite beading it was increased in 84.6 per cent. of cases.

Analysis of the range of plasma phosphatase results shows that in one hundred and forty-eight patients with no clinical evidence of rickets, the phosphatase was 10 units or less in 79.7 per cent., 10-15 units in 19.6 per cent., and above 15 units in 1.3 per cent. Sixty-nine patients with clinical evidence of rickets showed phosphatase values of 15-20 units in 44.9 per cent., and in the remainder the values were above 20 units.

Twelve patients with clinical signs of rickets and $\mathrm{x}$-rays showing evidence of healed rickets had phosphatase values below 10 units in 25 per cent. and 10-15 units in the remaining 75 per cent. A further group of thirty-one patients showed clinical evidence of rickets but in 61.3 per cent. the phosphatase was below 10 units and in the remainder 10-15 units. Twenty-four patients in this group showed mild beading of the ribs as the only sign, and fourteen of these cases had a phosphatase value below. 10 units. Five patients showed definite beading of the ribs, and three of these had phosphatase below 10 units.

Calcium and phosphorus estimations

TABLE 8C

CALCIUM AND PHOSPHORUS ESTIMATIONS

\begin{tabular}{|c|c|c|c|c|c|}
\hline Case No. & $\begin{array}{c}\text { Calcium } \\
\text { mgm. per cent. }\end{array}$ & $\begin{array}{l}\text { Phosphorus } \\
\text { mgm. per cent. }\end{array}$ & $\mathrm{Ca} \times \mathbf{P}$ & $\begin{array}{l}\text { Phosphatase } \\
\text { units }\end{array}$ & Clinical \\
\hline $\begin{array}{l}552 \\
600\end{array}$ & $\begin{array}{l}9 \cdot 8 \\
8 \cdot 6\end{array}$ & $3 \cdot 5$ & $\underline{34 \cdot 3}$ & $\begin{array}{l}20 \\
20\end{array}$ & $\begin{array}{l}\text { Ribs }+2 \\
\text { Ribs }+4\end{array}$ \\
\hline 645 & 10 & $2 \cdot 8$ & 28 & 78 & Ribs + 3 \\
\hline 747 & 8.04 & $4 \cdot 6$ & 36.98 & 21 & Ribs +3 \\
\hline 573 & $9 \cdot 8$ & $4 \cdot 38$ & $42 \cdot 9$ & $7 \cdot 5$ & $\begin{array}{l}\text { Convulsions, no evi- } \\
\text { dence of rickets }\end{array}$ \\
\hline
\end{tabular}

Blood calcium and phosphorus were estimated in five cases. In four of these patients there were clinical signs of rickets, phosphatase 20 units or more and the calcium phosphorus product was below 40. In one case, the child had convulsions but no clinical evidence of rickets. In this case the calcium and phosphorus were both within normal limits, and the phosphatase was below 10 units.

\section{Rate of gain in weight}

Three cases with clinical investigation only showed average rate of gain in one case, 0-25 per cent. above average in one case, and 25-50 per cent. below average in one case.

Two cases in which there were no clinical signs of rickets but the phosphatase was increased both showed an average rate of gain. 
TABLE 3C

CORRELATION BETWEEN GAIN IN WEIGHT AND MANIFESTATIONS OF RICKETS

\begin{tabular}{|c|c|c|c|c|c|}
\hline Gain in weight & $\begin{array}{c}\text { No } \\
\text { evidence }\end{array}$ & $\begin{array}{l}\text { Positive } \\
\text { clinical } \\
\text { and } \\
\text { phosphatase }\end{array}$ & $\begin{array}{c}\text { Positive } \\
\text { clinical, } \\
\text { negative } \\
\text { phosphatase }\end{array}$ & $\begin{array}{l}\text { Positive } \\
\text { clinical, } \\
\text { positive } \\
\text { X-ray } \\
\text { (healed) }\end{array}$ & Total No. \\
\hline $\begin{array}{l}\text { Average } . \\
0-25 \text { per cent. above average } \\
25-50 \text { per cent. above average } \\
50-100 \text { per cent. above average. } \\
0-25 \text { per cent. below average } \\
25-50 \text { per cent. below average } \\
50-100 \text { per cent. below average }\end{array}$ & $\begin{array}{r}111 \\
3 \\
3 \\
4 \\
8 \\
8 \\
15\end{array}$ & $\begin{array}{r}46 \\
1 \\
3 \\
2 \\
6 \\
11\end{array}$ & $\frac{24}{1}$ & $\begin{array}{c}9 \\
- \\
-1 \\
1 \\
1\end{array}$ & $\begin{array}{r}190 \\
4 \\
7 \\
4 \\
12 \\
17 \\
31\end{array}$ \\
\hline Total & 152 & 69 & 32 & 12 & 265 \\
\hline
\end{tabular}

In one hundred and fifty-two infants with no evidence of rickets, 73 per cent. had gained weight at an average rate. 20.3 per cent. showed a rate of gain below average, and 6.6 per cent. above average.

In sixty-nine infants with positive clinical signs and phosphatase positive, the rate of gain was average in 65.7 per cent., below average in 28.5 per cent. and above average in 5.8 per cent.

Twelve patients showed clinical and $\mathrm{x}$-ray evidence of healed rickets, but phosphatase was negative; 75 per cent. of these cases gained weight at an average rate, and 25 per cent. below average.

Thirty-two infants had clinical signs but no other evidence of rickets. 75 per cent. of these infants showed an average rate of gain in weight, and only one infant gained at a greater than average rate.

Two infants with no clinical signs but positive phosphatase both showed an average rate of gain in weight.

\section{Relationship of severity of disease to occurrence of rickets}

TABLE 2C

SEVERITY OF. DISEASE AND MANIFESTATIONS OF RICKETS

\begin{tabular}{|c|c|c|c|c|c|c|}
\hline Clinical evidence & Healthy & Minor & Moderate & Severe & $\begin{array}{l}\text { Twin or } \\
\text { premature }\end{array}$ & Total No. \\
\hline $\begin{array}{l}\text { None . . . . } \\
\text { Positive plus phosphatase . } \\
\text { Positive, phosphatase negative } \\
\text { Positive plus x-ray positive, } \\
\text { phosphatase negative } \\
\text { Clinical negative phosphatase } \\
\text { positive .. }\end{array}$ & $\begin{array}{r}10 \\
8 \\
1 \\
- \\
-\end{array}$ & $\begin{array}{r}41 \\
15 \\
3 \\
1 \\
-\end{array}$ & $\begin{array}{c}69 \\
\text { (1 negro) } \\
16 \\
2 \\
2 \\
2\end{array}$ & $\begin{array}{r}34 \\
18 \\
12 \\
1 \\
-\end{array}$ & $\begin{array}{c}11 \\
6 \\
\\
- \\
1\end{array}$ & $\begin{array}{r}154 \\
69 \\
32 \\
4 \\
4 \\
2\end{array}$ \\
\hline & 19 & 59 & 127 & 65 & 21 & - \\
\hline
\end{tabular}

6.5 per cent. of the infants showing no evidence of rickets were healthy. 33.7 per cent. were suffering from minor ailments, 44.8 per cent. were moderately ill, and the remainder were seriously ill. There were eleven twin or premature infants, i.e. $7 \cdot 1$ per cent.

11.6 per cent. of the infants in the group of clinical and phosphatase positive cases were healthy. 21.7 per cent. were minor ailments, 45 per cent. were moderately ill and one of these children was a negro; 26 per cent. were seriously ill. There were six twin or premature infants, i.e. 8.6 per cent.

3.1 per cent. of the group of cases showing clinical signs of rickets only were healthy. $9 \cdot 3$ per cent. had minor ailments, 50 per cent. were moderately ill, and 37.5 per cent. were seriously ill. 9 per cent. were twin or premature infants, one of the cases being a triplet.
In the group of cases showing clinical and x-ray evidence of rickets, there were no healthy infants, and no twin or premature infants. 50 per cent. of the infants were moderately ill. Three cases. with clinical examination only were moderately ill.

\section{Methods of feeding}

Three cases had a clinical examination only with no evidence of rickets. One case was breast fed nine months, one case had milk mixture, and one case had cereal additions to milk. All three cases. were on mixed diet from nine months.

Two cases were clinically negative with increased phosphatase, one had dried milk and the other milk mixture, and adequate vitamen $D$ supplement.

In this age group, all the infants were on some kind of mixed feeds at the time of examination. Twenty-three infants were on a poor mixed diet 
TABLE 4C

METHODS OF FEEDING

\begin{tabular}{|c|c|c|c|c|c|}
\hline Food & $\begin{array}{c}\text { No } \\
\text { evidence }\end{array}$ & $\begin{array}{c}\text { Positive } \\
\text { clinical } \\
\text { and } \\
\text { phosphatase }\end{array}$ & $\begin{array}{l}\text { Positive } \\
\text { clinical, } \\
\text { positive } \\
\text { x-ray }\end{array}$ & $\begin{array}{c}\text { Positive } \\
\text { clinical, } \\
\text { negative } \\
\text { phosphatase }\end{array}$ & Total No. \\
\hline 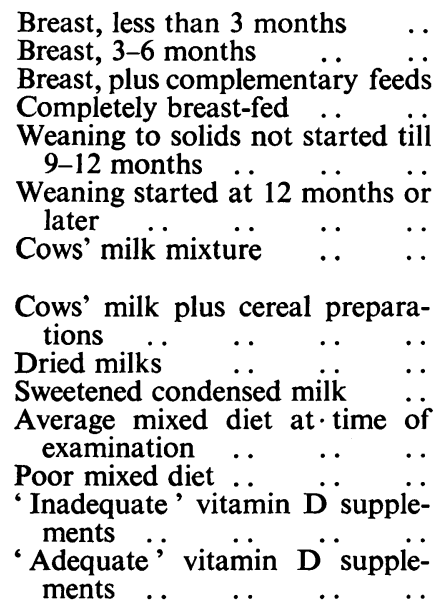 & $\begin{array}{r}8 \\
20 \\
8 \\
146 \\
8 \\
20 \\
43\end{array}$ & $\begin{array}{r}39 \\
12 \\
15 \\
14 \\
\\
1 \\
29\end{array}$ & $\begin{array}{r}.7 \\
5 \\
3 \\
3 \\
1 \\
9\end{array}$ & $\begin{array}{c}18 \\
8 \\
1 \\
4 \\
4 \\
\overline{22} \\
\text { Goat's milk 1 } \\
-\overline{2} \\
2\end{array}$ & $\begin{array}{r}149 \\
46 \\
2 \\
69 \\
56 \\
5 \\
9 \\
115 \\
\\
\\
13 \\
33 \\
17\end{array}$ \\
\hline
\end{tabular}

which consisted chiefly of cereals and milk or sweetened condensed milk. Eight of these infants (33 per cent.) showed no evidence of rickets, and 50 per cent. showed positive clinical and phosphatase.

One hundred and fifty-four infants were breast-fed less than three months, i.e. 56 per cent. Forty-six infants were breast fed from three to six months (16.9 per cent.) and seventy infants were completely breast fed until weaned to solid foods, i.e. $25 \cdot 7$ per cent. 67 per cent. of the completely breast-fed infants showed no evidence of rickets. 21.7 per cent. showed increased phosphatase and clinical evidence of rickets. 45 per cent. of the infants breast fed for three to six months showed no evidence of rickets.

One hundred and seventeen infants were fed on cows' milk mixture, and of these 42.6 per cent. showed no evidence of rickets, and 26 per cent. were definitely positive, while a further 19 per cent. showed some clinical evidence with negative phosphatase.
Fourteen infants had received starch additions to cows' milk. Nine of these infants showed no evidence of rickets, and five showed positive clinical and phosphatase tests.

. Thirty-four infants were fed on dried milks, and twenty showed no evidence of rickets.

Seventy infants were fed on sweetened condensed milk, and eight showed no evidence of rickets.

One hundred and twenty-six infants had received some vitamin D supplement. This was inadequate in thirty-nine cases ( 31 per cent.). 51 per cent. showed no evidence of rickets when the supplement was inadequate, and 50.6 per cent. showed no evidence when the supplement was adequate. There was definite clinical evidence in 29 per cent. of this latter group, with positive phosphatase, and in 15 per cent. with negative phosphatase. Whereas in the cases who had received an inadequate supplement there were positive clinical and phosphatase findings in 30 per cent.

Maternal diet during pregnancy

TABLE 5C

MATERNAL DIET DURING PREGNANCY

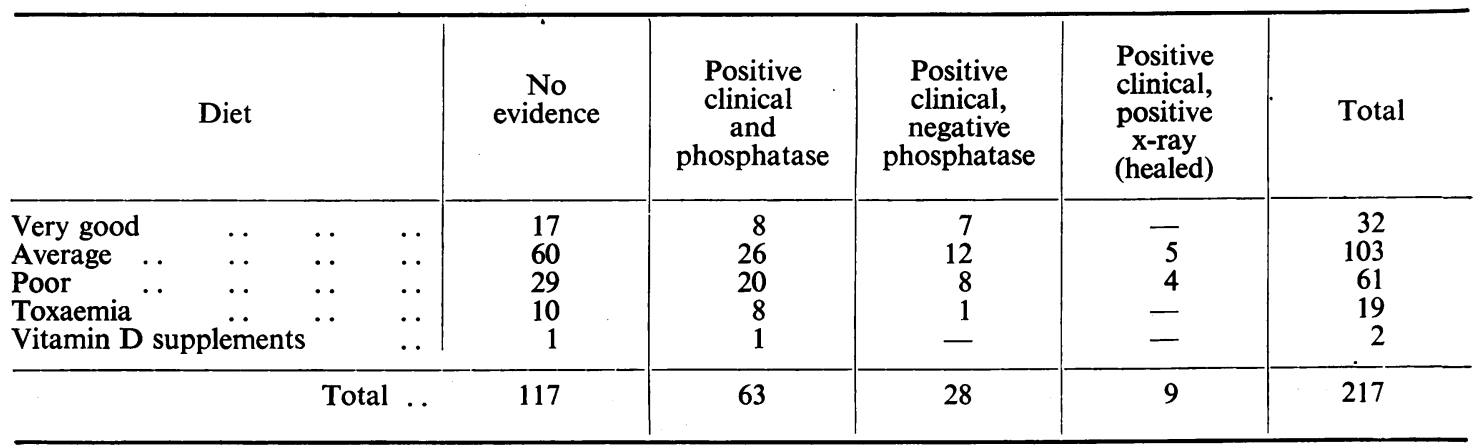


Information concerning diet of the mother during pregnancy was available in two hundred and twenty cases.

In 48 per cent. of the cases the diet was average. In 18 per cent. the diet was very good, and in 28 per cent. it was poor. Nineteen cases ( 8.6 per cent.) were on carbohydrate diet for toxaemia during the later part of the pregnancy. Only two patients received any vitamin $\mathrm{D}$ additions to the diet.
When the mother's diet had been very good, 53 per cent. of the patients showed no evidence of rickets, and 25 per cent. showed definitely positive evidence.

58 per cent. of the patients showed no evidence when the mother had received an average diet, and 47.5 per cent. showed no evidence when the diet was poor. 49 per cent. of the toxaemic cases showed no evidence of rickets.

Economic status

TABLE 6C-.ECONOMIC STATUS OF THE FAMILY AND ENVIRONMENT

\begin{tabular}{|c|c|c|c|c|c|c|c|c|}
\hline \multicolumn{4}{|c|}{$\begin{array}{l}\text { Status (1-4) and } \\
\text { environment (5-9) }\end{array}$} & No evidence & $\begin{array}{c}\text { Positive } \\
\text { clinical and }\end{array}$ & $\begin{array}{l}\text { Positive } \\
\text { clinical }\end{array}$ & $\begin{array}{c}\text { Positive clinical, } \\
\text { negative }\end{array}$ & Total No. \\
\hline $\begin{array}{l}\text { 1. Comfort } \\
\text { 2. Sufficiency } \\
\text { 3. Insufficiency } \\
\text { 4. Poverty } \\
\text { 5. Very good } \\
\text { 6. Good .. } \\
\text { 7. Fair .. } \\
\text { 8. Poor .. } \\
\text { 9. Bad .. }\end{array}$ & $\begin{array}{l}\ldots \\
\cdots \\
\cdots \\
\cdots \\
\cdots \\
\cdots \\
\cdots\end{array}$ & $\begin{array}{l}\cdots \\
\cdots \\
\cdots \\
\cdots \\
\cdots \\
\cdots \\
\cdots\end{array}$ & $\begin{array}{l}\cdots \\
\cdots \\
\cdots \\
\cdots \\
\cdots \\
\cdots \\
\cdots \\
\cdots\end{array}$ & $\begin{array}{r}9 \\
17 \\
18 \\
26 \\
54 \\
24 \\
36 \\
27 \\
13\end{array}$ & $\begin{array}{r}-10 \\
11 \\
23 \\
17 \\
7 \\
16 \\
20 \\
12\end{array}$ & $\begin{array}{l}- \\
3 \\
1 \\
6 \\
3 \\
3 \\
1\end{array}$ & $\begin{array}{r}1 \\
4 \\
3 \\
1.1 \\
7 \\
9 \\
6 \\
6 \\
4\end{array}$ & $\begin{array}{l}10 \\
31 \\
35 \\
61 \\
84 \\
43 \\
58 \\
56 \\
30\end{array}$ \\
\hline
\end{tabular}

The economic status of one hundred and thirtyseven patients in the group was known. Ten patients were living in comfort, of whom nine showed no evidence of rickets. Thirty-one patients had sufficiency and seventeen of these (55 per cent.) showed no evidence of rickets. Thirty-five patients had insufficiency and eighteen of these (51 per cent.) showed no evidence of rickets. Sixty-one patients were living in poverty and 42.6 per cent. of these showed no evidence of rickets.

Environment. 31.6 per cent. of the patients were living in very good surroundings, and in this group, 64 per cent. showed no evidence of rickets. 15.8 per cent. of the patients lived in good surroundings and 56 per cent. showed no evidence.

21 per cent. of the patients lived in fair environment, and 62 per cent. showed no evidence of rickets.
21 per cent. lived in a poor environment, and 48 per cent. showed no evidence of rickets.

11 per cent. lived in a bad environment, and 43 per cent. showed no evidence of rickets.

Correlation of age and manifestations of rickets. Forty-five patients were aged twelve months, of whom 60 per cent. showed no evidence of rickets.

Seventy-three patients were aged twelve to fifteen months, of whom 46 per cent. showed no evidence.

Seventy-one patients were aged fifteen to eighteen months of whom 50 per cent. showed no evidence.

Forty-seven patients were aged eighteen to twenty-one months, and 63.8 per cent. showed no evidence.

Thirty-eight patients were aged twenty-one to twenty-four months and 81.5 per cent. showed no evidence.

TABle 9.-AGE RANGE OF PATIENTS

\begin{tabular}{|c|c|c|c|c|c|c|c|c|}
\hline & Age & & & No evidence & Positive rickets & Clinical & Phosphatase & Total \\
\hline $\begin{array}{l}\text { Below } 1 \text { month } \\
2 \text { months } \\
3 \text { months } \\
4 \text { months } \\
5 \text { months } \\
6 \text { months } \\
7 \text { months } \\
8 \text { months } \\
9 \text { months } \\
10 \text { months } \\
11 \text { months } \\
12 \text { months } \\
12-15 \text { months } \\
15-18 \text { months } \\
18-21 \text { months } \\
21-24 \text { months }\end{array}$ & $\begin{array}{l}\ldots \\
\ldots \\
\ldots \\
\ldots \\
\ldots \\
\ldots \\
\ldots \\
\ldots \\
\ldots \\
\ldots \\
\ldots \\
\ldots\end{array}$ & $\begin{array}{l}\ldots \\
\ldots \\
\ldots \\
\ldots \\
\cdots \\
\cdots \\
\cdots \\
\cdots \\
\cdots \\
\cdots \\
\cdots \\
\cdots \\
\cdots\end{array}$ & $\begin{array}{l}\ldots \\
\ldots \\
\ldots \\
\ldots \\
\ldots \\
\ldots \\
\ldots \\
\ldots \\
\ldots \\
\ldots \\
\ldots \\
\ldots \\
\ldots \\
\ldots\end{array}$ & $\begin{array}{r}21 \\
67 \\
41 \\
23 \\
22 \\
19 \\
17 \\
16 \\
20 \\
9 \\
12 \\
27 \\
33 \\
35 \\
30 \\
31\end{array}$ & $\begin{array}{r}3 \\
23 \\
24 \\
18 \\
26 \\
11 \\
9 \\
10 \\
9 \\
5 \\
13 \\
11 \\
31 \\
26 \\
12 \\
3\end{array}$ & $\begin{array}{r}7 \\
23 \\
11 \\
7 \\
7 \\
6 \\
5 \\
7 \\
3(+1) \\
6(+1) \\
4 \\
6 \\
8 \\
9 \\
5 \\
4\end{array}$ & $\begin{array}{r}\overline{12} \\
8 \\
5 \\
- \\
- \\
2 \\
1 \\
- \\
-1 \\
-\end{array}$ & $\begin{array}{r}31 \\
125 \\
84 \\
53 \\
55 \\
36 \\
31 \\
35 \\
35 \\
22 \\
29 \\
45 \\
73 \\
71 \\
47 \\
38\end{array}$ \\
\hline
\end{tabular}

7 cases noi investigated completely below 6 months. 


\section{Discussion}

1. Diagnosis of rickets. Eight hundred and twenty infants were investigated. A clinical examination was made in every case, and the presence or absence of the two cardinal signs of rickets, craniotabes and enlargement of the costo-chondral junctions, was noted. Other signs such as bow-legs or genu valgum were noted as additional clinical evidence of rickets. The plasma phosphatase was estimated in seven hundred and ninety-seven cases. One hundred and nineteen patients were x-rayed, in fourteen of these cases the plasma phosphatase was not estimated. In nine cases a clinical examination only was made.

A patient was considered to show no evidence of rickets if at least two of these three investigations were negative, with the exception of those cases in which no examination other than clinical was made, but even there post-mortem confirmation was available in a few cases. Judged by these criteria, four hundred and thirteen patients showed no evidence of rickets or 50.36 per cent. of all cases. Considering the various age groups, in the youngest group 48.6 per cent. showed no evidence, in group II, $49 \cdot 3$ per cent. showed no evidence, and in group III, 53.2 per cent. showed no evidence.

A patient was considered to show definite evidence of rickets if at least two criteria were fulfilled. These were definite clinical signs with either raised phosphatase or positive $\mathrm{x}$-ray, or post mortem. In some cases all these criteria were fulfilled. In two hundred and forty-five cases the phosphatase and clinical signs were positive, i.e. $30 \cdot 6$ per cent. of all cases in whom the phosphatase was estimated. These findings were confirmed radiologically in seventy-four cases, and in a further thirteen cases the clinical and $\mathrm{x}$-ray were positive, the latter indicating healed rickets, whereas the phosphatase was below 15 units. In one case there was positive clinical and post-mortem evidence only. Therefore in two hundred and fifty-nine infants there were definite signs of rickets, which is 31.4 per cent. of all cases investigated.

In considering the value of the clinical signs of rickets, it may be noted that in this group of definite cases, the occurrence of clinical signs was as follows:

\begin{tabular}{|c|c|}
\hline Craniotabes only & $\begin{array}{l}4 \text { cases, all under six } \\
\text { months. }\end{array}$ \\
\hline \multicolumn{2}{|l|}{ CRANIOTABES WITH BEADED } \\
\hline $\begin{array}{lll}\text { RIBS } & \cdots & \cdots\end{array}$ & $\begin{array}{l}27 \text { cases, } 21 \text { under six } \\
\text { months. }\end{array}$ \\
\hline SEVERE BEADING OF RIBS & 14 cases. \\
\hline MARKED BEADING & 46 cases. \\
\hline DEFINITE BEADING & 83 cases. \\
\hline MILD BEADING $\ldots$ & 29 cases. \\
\hline OTHER SIGNS & $\begin{array}{c}\text {.. } 34 \text { cases, } 30 \text { cases in } \\
\text { group III. }\end{array}$ \\
\hline
\end{tabular}

Craniotabes would appear to be a common sign of rickets during the first six months, but when occurring without beading of the ribs it may not be diagnostic, as in this series only four in seven cases had raised phosphatase or positive $\mathrm{x}$-ray findings. Every case in which beading of the ribs was present in addition to craniotabes also fulfilled at least one of the other criteria, and 77.7 per cent. of these cases occurred in the first six months of life.

Definite beading (plus 2) was the commonest clinical sign in all age groups, and was found in 41 per cent. of the positive cases who showed any beading of the ribss. Marked beading (plus 3) was the second most common sign, occurring in 23 per cent. of cases showing any beading. Other signs of rickets which included deformities of long bones were practically confined to the oldest group of patients.

There was a group of one-hundred and nineteen patients in whom clinical signs of rickets were present but the phosphatase was less than 15 units. In this group post mortem and $\mathrm{x}$-ray in a few cases also showed no evidence of rickets.

Analysis of this group of cases shows that in eighty cases (67 per cent. of the group) the only clinical sign of rickets was mild beading of the ribs (beading plus one). In twenty-seven cases ( 22 per cent.) definite beading was present. In two cases only was severe beading present, and in one case gross beading. In the remaining cases which were all in the oldest group the diagnosis was made on the finding of bow-legs. These findings contrast sharply with the group of definitely positive cases where only 11.8 per cent. of cases show mild beading, and 41 per cent. showed definite beading.

There was a fourth group of twenty-eight patients, of whom twenty-one were in the youngest group of patients, who showed no clinical evidence of rickets but in whom the phosphatase was raised above 15 units.

Comparison of the values for plasma phosphatase and the corresponding clinical findings reveals the following points:

1. 78 per cent. of the four hundred and thirteen cases who showed no evidence of rickets by two or more criteria were found to have plasma phosphatase of 10 units or lower. This figure was approximately the same for all ages.

2. 45 per cent. of the cases with mild beading of the ribs and low phosphatase values, were found to have phosphatase below 10 units, and these cases formed 31 per cent. of all cases showing mild beading of the ribs.

38 per cent. of all cases showing mild beading of the ribs had a phosphatase value between 10 .and 15 units, the highest percentage of cases being in the first age group.

3. 25 per cent. of all cases showing definite beading of the ribs gave phosphatase values below 15 units, and of these cases 48 per cent. had phosphatase-of 10 units or lower.

4. Three cases with craniotabes as the only sign of rickets had phosphatase values below 15 units, and in each case the figure was above 10 units.

5. 48 per cent. of the definitely positive cases had phosphatase values of 15 to 20 units.

6. 90.6 per cent. of those cases who showed no clinical evidence of rickets but in whom there was an 
increase in plasma phosphatase, showed phos- Group II 6-12 months. phatase values of 15 to 20 units.

From these figures the following conclusions may be drawn:

1. The majority of children in this age range who show no clinically detectable abnormality of ossification of the ribs or skull have a normal plasma phosphatase range of 3 to 10 units.

2. Slight beading of the ribs is a doubtful clinical sign of rickets as it is found with normal or slightly raised plasma phosphatase in 81 per cent. of all cases showing mild beading, distributed approximately equally throughout the age range covered by the investigation.

3. Raised phosphatase values are found with definite beading of the ribs in the majority of cases, 75 per cent. having phosphatase values above 15 units, and 88 per cent. above 10 units, so that this clinical finding may be considered diagnostic of mild rickets.

4. Craniotabes with beading of the ribs was associated with a raised plasma phosphatase in all cases.

5. The group of cases showing no clinical evidence of rickets but with raised phosphatase values is difficult to interpret, but since 78 per cent. of these cases occurred in the youngest age group this would appear to be a significant finding and may indicate that some abnormality of ossification is occurring which cannot yet be detected clinically, as has been suggested by Morris (1937).

It is worthy of note that in this whole series of cases, there was only one case of clinical tetany, and that only six cases could be stated to be suffering from severe rickets above the age of six months, and below that age there were twenty-one cases with craniotabes and beaded ribs who might be stated to show evidence of severe rickets.

\section{Factors relevant to the incidence of rickets}

1. Age. It will be noted that in this series two hundred and forty patients were below the age of three months. Fifty of these cases showed definite clinical evidence of rickets and phosphatase raised above 15 units. The youngest patient was aged two weeks.

The highest incidence of rickets was found at ages six to nine months when there were 52.5 per cent. of positive cases. The second highest period was twelve to eighteen months with an incidence of 48 per cent.

In the three main age groups the incidence is as follows:

Group I 0-6 months. $26 \cdot 2$ per cent. definite cases.

$10 \cdot 3$ per cent. doubtful cases with slight increase in phosphatase and some clinical signs.

7 per cent. of possible early cases with no clinical signs but definite increase in phosphatase.
Goup III 1-2 years.

$30 \cdot 3$ per cent. definite cases.

$20 \cdot 2$ per cent. doubtful cases.

$2 \cdot 6$ per cent. possible early cases.

29.5 per cent. definite cases.

$4 \cdot 7$ per cent. doubtful cases.

0.7 per cent. possible early cases.

The higher incidence of cases with raised phosphatase only in the first age group would appear to be strongly in support of the suggestion that an increase in phosphatase may precede clinical signs of rickets.

The increase in number of cases with clinical signs but phosphatase only raised to 10 to 15 units in the 6 to 12 months age group may be due to healing taking place at this age with consequent lowering in phosphatase values.

2. FeEding. It will be noted that four hundred and fifty-seven infants (i.e. $55 \cdot 7$ per cent.) were weaned before the age of three months Information was available for the youngest group of patients that one hundred and seventy-nine were weaned before the age of six weeks.

The incidence of definite cases of rickets in the infants artificially fed by all means from three months or earlier is 33 per cent., as compared with the figure of 26.4 per cent. for infants wholly or partially breast-fed̨.

Analysis of the methods of artificial feeding reveals that three hundred and eighteen infants were fed on cows' milk mixture, in seventy-one cases the quantity of milk was gradually increased from equal parts milk and water, and in five cases the mixture was weaker than equal parts. Thus two hundred and forty-two infants were fed on a milk mixture consisting of equal parts cows' milk and water with added sugar. 31.4 per cent. of infants fed on cows' milk mixture showed definite evidence of rickets.

Fifty-three infants received some cereal addition to cows' milk, and 24.5 per cent. showed definite evidence of rickets.

One hundred and twenty-two infants received dried milks: 31.9 per cent. of these infants showed definite evidence of rickets.

Forty-six infants were fed on sweetened condensed milk, and 30.4 per cent. showed definite evidence of rickets.

From these figures it would appear that the incidence was highest in infants fed on dried milks, but it should be noted that a certain number of cases were infants with feeding problems who had been tried on several methods first. The incidence is significantly lower in breast-fed infants.

Solid feeding was started in two hundred and one infants below the age of nine months, or 43 per cent. of infants over six months of age. Eleven infants received no solid food till one year or older. The majority of infants who had been weaned at the time of examination were receiving a diet containing 
at least one pint of milk daily, vegetables, cereals, bread and butter, and eggs.

Two hundred and forty-two infants were receiving some sort of vitamin D supplement, i.e. 29 per cent. of all infants examined. In ninety-six cases this was less than the minimum adequate amount; in many of the cases it consisted only of a small amount of butter or a proprietary preparation added to feeds. 41.6 per cent. of patients receiving an inadequate supplement showed evidence of rickets, and 42 per cent. of patients receiving an adequate supplement showed evidence of rickets. These findings indicate that added vitamin $D$ in the diet alone will not prevent the development of rickets if other factors are responsible, or that the adequate quantity of vitamin D should be greater than 400 units daily.

3. Health of the infants. There were one hundred and thirty-one healthy infants, of whom one hundred and four were in the youngest age group, 40.4 per cent. of these infants showed definite evidence of rickets.

One hundred and thirty-seven infants were suffering from minor ailments, of whom 31.4 per cent. showed definite evidence of rickets.

Two hundred and ninety-seven infants were moderately ill, of whom 29.6 per cent. showed definite evidence of rickets.

Two hundred and forty-five infants were severely ill, of whom 24.9 per cent. showed evidence of rickets.

It will be seen from these figures that the incidence of rickets appears to be in inverse ratio to the degree of severity of illness. This may be partly accounted for by the fact that many of the cases in the severely-ill class were infants with severe marasmus, gastro-enteritis, coeliac disease and other gross disturbances of nutrition which interfered seriously with growth.

4. RATE of Gain IN Weight. Cases with no evidence of rickets showed an average rate of gain in 44.6 per cent., 58 per cent. and 73 per cent. in groups I, II and III respectively, and in the three groups 11.8 per cent., 15 per cent. and 6.6 per cent. were above average.

Cases with definite evidence of rickets showed an average rate of gain in weight in 57.4 per cent., 63 per cent. and 65.7 per cent. in the three groups, and above average in 17 per cent., 14 per cent. and $5 \cdot 8$ per cent. of cases.

Rates of gain below average were found in 35 per cent., 26.9 per cent. and 20.3 per cent. of cases with no evidence of rickets, whereas in those definite cases of rickets, rates of gain were below average in 19.1 per cent., 22.8 per cent. and 28.5 per cent. in the three groups.

It will be seen that more cases were below average weight than above, and that the incidence of rickets seemed to bear no definite relationship to the rate of gain, except possibly in the oldest children in whom a larger number of cases of rickets were found in the infants who were below average.

5. INCIDENCE OF TWIN AND PREMATURE INFANTS.
There were sixty-two twin or premature infants, i.e. $7 \cdot 6$ per cent. of all infants examined. 30.6 per cent. of these infants showed definite evidence of rickets, the incidence being 61 per cent. in the group of infants below six months old, so that twin or premature infants would appear to be about twice as liable to develop rickets during the first six months as other infants.

6. ANTENATAL DIET OF THE MOTHER. In each age group there appeared to be a definite relationship of the incidence of rickets to the antenatal diet of the mother. Throughout the series an average of 14 per cent. of mothers had been very well fed during pregnancy, and 63.6 per cent. of their babies showed no evidence of rickets, the lowest incidence being in the six to twelve months age group. 51 per cent. had an average diet and 43.4 per cent. of their infants showed no evidence. 30.6 per cent. of the mothers had a poor diet and 39 per cent. of their infants showed no evidence of rickets.

The maternal diet might be expected to affect the infant for the first six months of life, but this relationship of diet to incidence of rickets is seen in all three age groups and therefore it is probable that the maternal diet forms an index to the general standard of living of the family and it would appear probable that when the mother has a poor diet the infant would also be weaned on to a mainly carbohydrate type of diet.

7. ENVIRONMENT. In each age group the incidence of rickets is lowest in patients. who lived in a good or very good environment with regard to accessibility of direct sunlight.

During the first six months of life the incidence of rickets was about 10 per cent. higher in patients who lived in a fair environment, but in the other age groups there was little difference in the incidence. from the better environments.

The incidence was definitely increased in patients who came from poor or bad homes and this particularly applied to the two older groups of patients.

It may be noted that $9 \cdot 4$ per cent. of all the patients were living in a bad environment, and 20.8 per cent. lived in poor surroundings.

8. Economic Status. The economic status of two hundred and ninety patients was known. $45 \cdot 2$ per cent. of these patients were living in poverty, and 36.5 per cent. of these patients showed no evidence at all of rickets. In comparison with these figures, 9.4 per cent. of the patients were living in comfort, of whom 58.7 per cent. showed no evidence of rickets. 24.5 per cent. were living in a state of sufficiency of whom $51 \cdot 1$ per cent. had no evidence of rickets, and 16 per cent. had insufficiency of whom 49 per cent. had no evidence. These figures show the greatest incidence of rickets in the poorest patients.

\section{Summary and conclusions}

1. Eight hundred and twenty patients were investigated for evidence of rickets, in the age range of two weeks to two years. 
2. The diagnosis of rickets was based on clinical findings in association with plasma phosphatase estimations, $x$-rays and post-mortem findings.

3. The incidence of definite cases of rickets in which there were clinical signs and either $\mathrm{x}$-ray evidence or an increase in the plasma phosphatase above 15 units, was 31.4 per cent.

4. A further 3.9 per cent. of patients may be considered to be early cases, since they showed no clinical evidence of rickets but the phosphatase was raised above 15 units. 75 per cent. of these cases were below six months of age.

5. $14 \cdot 5$ per cent. of cases showed some clinical signs suggestive of rickets, but other investigations were negative. 67 per cent. of these cases showed mild beading of the ribs only, and 52 per cent. of these had phosphatase values of 10 to 15 units, so these latter cases may be considered to have some mild abnormality of ossification. A further 22.7 per cent. of these cases showed some other evidence of rickets with the phosphatase raised to 10 to 15 units. Therefore a further $8 \cdot 3$ per cent. of all cases examined may be said to show doubtful or slight evidence of rickets.

6. Plasma phosphatase was estimated on seven hundred and ninety-seven cases. The value of this test in the diagnosis of rickets is discussed, and it is found that there is a close correlation between an increase in the plasma phosphatase and definite enlargement of the costo-chondral junctions, but when the enlargement is only slight the phosphatase is below 15 units in 81 per cent. of cases, so that slight enlargement of costo-chondral junctions alone is not diagnostic of rickets.

7. Certain factors relevant to the incidence of rickets were investigated. These included age of patients, method of feeding, rate of gain in weight, and type of disease or condition for which the infant was brought to hospital. In addition, the mother's diet during pregnancy, the type of neighbourhood where the child lived, and, in some cases, the economic status of the family were determined.

8. The incidence of rickets was greatest during the period six to nine months, when it was 52 per cent., and from twelve to eighteen months, when it was 48 per cent. Below the age of six months there were $26 \cdot 2$ per cent. of definite cases.

9. The incidence of rickets is 5 per cent. lower in breast-fed infants than in artificially-fed infants, but during the first six months the incidence is 13 per cent. lower than the average in breast-fed infants, whereas in the second age group the incidence is 10 per cent. higher in breast-fed infants than the average figure. There is little difference in the incidence of rickets in infants who were fed on either dried milks, milk mixture, or sweetened condensed milk.

10. 29 per cent. of infants had received some vitamin $\mathrm{D}$ addition to the diet. In 39.6 per cent. of cases this supplement contained less than 400 units of vitamin D daily. The incidence of rickets in cases who had received the supplement was 10 per cent. higher than in the other cases.

11. There appears to be a definite relationship between the severity of the condition for which the child attended hospital and the incidence of rickets. The highest incidence being found in the healthy infants, and the lowest in the severely ill.

12. The incidence of rickets did not appear to show any very definite relationship to rate of gain in weight, except in the youngest group of infants, in whom there was an average or high rate of gain in weight in a greater proportion of cases than in the other two groups. In the oldest age group there was a higher percentage of rickets in infants who were below average weight than in the other two groups.

13. The incidence of rickets in twin and premature infants is not greater than the average for the whole age range, but in the youngest group of patients the incidence is doubled in the twin and premature infants.

14. There appeared to be a definite relationship between the incidence of rickets and the type of antenatal diet of the mother. This relationship was constant throughout the three age groups, the incidence of rickets being greatest when the mother's diet was poor.

15. Environment appears to play a considerable part in the incidence of rickets. The smallest number of cases being found in those infants who came from a good or very good neighbourhood with regard to accessibility of direct sunlight.

16. The incidence of rickets is related to the economic status of the family, being highest in those patients who are living in poverty.

An acknowledgement must be made to the University of Bristol for permission to publish the results of this investigation which was undertaken during the tenure of the Beaverbrook Fellowship, 1938-41. Grateful thanks are due to Professor Bruce Perry for much helpful advice and for providing laboratory facilities, and to other members of the Honorary Staff of Bristol Children's Hospital whose cases were included in the investigation. Thanks are also due to Dr. Richard Clarke who gave much valuable help in confirming clinical findings, and permission to use his cases at the Bristol Royal Infirmary.

\section{REFERENCES}

Chisholm, C. (1933). Brit. J. Child. Dis., 30, 84.

Jenner, H. D., and Kay, H. D. (1932). Brit. J. exp. Path., 13, 22.

Kay, H. D. (1930). J. biol. Chem., 89, 249.

King, E. J., and Armstrong, A. R. (1934). Canad. med. Ass. J., 31, 376.

-, Haslewood, G. A., and Delory, G. E. (1937). Lancet, 1, 886.

Mackay, H. (1926). Arch. Dis. Childh., 1, 33.

Morris, N., Stevenson, M., Peden, O., and Small, J. (1937). Ibid., 12, 45 .

Smith, J. (1933). Ibid., 8, 215.

Stearns, G., and Warweg, E. (1933). J. biol. Chem., 102, 745 .

Tout, H. (1938). The standard of living in Bristol, p. 26. 